"Climate Dynamics" manuscript No.

(will be inserted by the editor)

\title{
Time-dependent response of a zonally averaged ocean-atmosphere-sea ice model to Milankovitch forcing
}

\author{
Andrés Antico · Olivier Marchal · Lawrence A. \\ Mysak
}

Received: date / Accepted: date

\begin{abstract}
An ocean-atmosphere-sea ice model is developed to explore the time-dependent response of climate to Milankovitch forcing for the time interval 5-3 Myr BP. The ocean component is a zonally averaged model of the circulation in five basins (Arctic, Atlantic, Indian, Pacific, and Southern Oceans). The atmospheric component is a one-dimensional (latitudinal) energy balance model, and the sea-ice component is a thermodynamic model. Two numerical experiments are conducted. The first experiment does not include sea ice and the Arctic Ocean; the second experiment does. Results from the two experiments are used to investigate (i) the response of annual mean surface air and ocean temperatures to Milankovitch forcing, and (ii) the role of sea ice in this response.

In both experiments, the response of air temperature is dominated by obliquity cycles at most latitudes. On the other hand, the response of ocean temperature varies with latitude and depth. Deep water formed between $45^{\circ} \mathrm{N}-65^{\circ} \mathrm{N}$ in the Atlantic Ocean mainly responds to precession. In contrast, deep water formed south of $60^{\circ} \mathrm{S}$ responds to obliquity when sea ice is not included. Sea ice acts as a time-integrator of summer insolation changes such that annual mean sea-ice conditions mainly respond to obliquity. Thus, in the presence of sea ice, air temperature changes over the sea ice are amplified, and temperature changes in deep water of southern origin are suppressed since water below sea ice is kept near the freezing point.
\end{abstract}

A. Antico

Department of Atmospheric and Oceanic Sciences, McGill University, 805 Sherbrooke Street West, Montréal, Quebec, H3A 2K6, Canada

Tel.: +1-514-398-7448

Fax: +1-514-398-6115

E-mail: andres.antico@mail.mcgill.ca

O. Marchal

Department of Geology and Geophysics, Woods Hole Oceanographic Institution, Woods Hole, MA 02543, USA

L. A. Mysak

Department of Atmospheric and Oceanic Sciences, McGill University, 805 Sherbrooke Street West, Montréal, Quebec, H3A 2K6, Canada 


\section{Introduction}

The solar radiation at the top of the atmosphere (insolation) constitutes the main external forcing on the climate system. The term "Milankovitch forcing" refers to the long-term insolation variations that result from changes in the geometry of the Earth's orbit around the Sun. Eccentricity, obliquity, and the position of the equinoxes along the orbit change in time with approximate periods of 400 and $100 \mathrm{kyr}, 41 \mathrm{kyr}$, and 19 and $23 \mathrm{kyr}$, respectively. Geologic records suggest that climate has varied at these periods in the past (e.g., Tiedemann et al 1994; Petit et al 1999; Jouzel et al 2007; Lisiecki and Raymo 2005; 2007). However, much of this variability remains without quantitative explanation.

Marine sediment records show evidence of climate variability driven by Milankovitch forcing during the early and middle Pliocene (5-3 Myr BP) (e.g., Tiedemann et al 1994; Lisiecki and Raymo 2005; 2007), when large continental ice sheets were apparently absent in the Northern Hemisphere (Shackleton et al, 1995). Simplified and computationally efficient climate models have been used to study the evolution of a land-ice-free climate under the influence of Milankovitch forcing. For example, the climate response to Milankovitch forcing over the last 3.2 Myr was investigated by Brickman et al (1999) (hereafter BHW99) using a zonally averaged model of ocean circulation in three basins coupled to an energy balance model of the atmosphere. This study revealed the potential role of ocean circulation in filtering climatic responses to Milankovitch forcing. For example, the response of global mean ocean temperature to eccentricity forcing was muted owing to the influence of the meridional overturning circulation in the Atlantic Ocean.

The findings of BHW99 should be interpreted in the context of models in which several processes were deliberately omitted. For example, changes in the hydrological cycle and the ice-albedo feedback were not included. Moreover, in spite of the use of a climate model with latitudinal resolution in all its components (and vertical resolution in the ocean model), BHW99 only analyzed global means of surface air and ocean temperatures. Although interesting results were obtained through this approach, interpreting paleoclimate data from specific locations requires understanding of the spatial structure of model responses.

Here the work of BHW99 is extended (i) by analyzing the spatial structure of the responses of surface air and ocean temperatures to Milankovitch forcing, and (ii) by including sea ice. The ocean-atmosphere-sea ice model used in this study is largely based on the zonally averaged ocean-atmosphere model of Stocker et al (1992). In spite of the extensions introduced in this paper, important limitations are still present. For example, the model does not represent three-dimensional ocean processes, sea-ice dynamics, the atmospheric circulation, an active hydrological cycle (the model has a fixed hydrological cycle), and the carbon cycle. Likewise, our model does not include an ice sheet component, so the response of a warm climate (i.e., without large ice sheets on the continents) could only be investigated. Following an approach common to previous studies, a simplified model is used to isolate some of the fundamental processes involved in the response of the climate system to Milankovitch forcing.

This paper is organized as follows. Section 2 describes the climate model, the experimental design, and the Milankovitch forcing. In section 3, results from a modern climate equilibrium solution are compared to modern observations. In section 4 , results from two time-dependent solutions (with and without sea ice) for the time interval 5-3 Myr BP are presented. The climate response to Milankovitch forcing in these two solutions is discussed and interpreted in section 5. Finally, conclusions are given in section 6. 


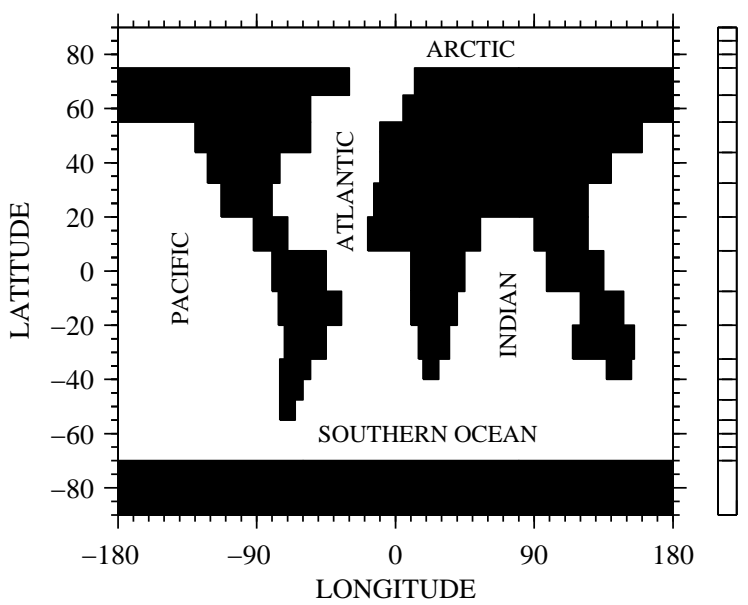

Fig. 1 Land-sea configuration of the model. The model components have the latitudinal resolution shown by the sidebar. A flat bottom is considered with a depth of $5(3.5) \mathrm{km}$ south (north) of $65^{\circ} \mathrm{N}$. In the ocean model, fifteen grid cells are considered in the vertical direction. The bottom of these cells is at the depths of 70, 150, $250,500,750,1000,1250,1500,2000,2500,3000,3500,4000,4500$, and $5000 \mathrm{~m}$.

\section{Methodology}

\subsection{Climate model}

The seasonal and zonally averaged ocean-atmosphere-sea ice model (Fig. 1) is briefly described. The ocean component is that of Wright and Stocker (1992). The atmospheric component is a modified version of the one-dimensional (latitudinal) EBM of Stocker et al (1992). The sea-ice model is based on the "zero-layer" model of Semtner (1976) for determining changes in ice thickness and on the parameterizations of Parkinson and Washington (1979) for calculating ice concentration. The model components, model spinup and output saving procedures, and atmospheric model parameters are detailed in Appendixes A, B and C, respectively.

\subsection{Experimental design}

Two time-dependent solutions for the interval 5-3 Myr BP are obtained by integrating two different model versions under Milankovitch forcing (see section 2.3 for a description of this forcing). For each solution, model outputs averaged over the last 100 years of a modern climate spin-up run are used as initial conditions. The interval 5-3 Myr BP is considered because the Earth's land-sea configuration was then similar to present day and because paleoclimate data suggest that large northern continental ice sheets, not considered in this study, were small or absent during this interval.

In order to investigate the impact of sea ice, we consider one solution obtained with the sea-ice model coupled to the other model components (ICE) and another solution without any representation of sea ice (NOICE). The climate model used for ICE is described in Appendix A. For the experiment NOICE, some modification in the atmospheric and ocean components are needed because in the absence of sea ice, the ocean mixed layer temperature can drop several degrees below the freezing point in polar regions. In order to avoid unrealistic subfreezing temperatures, two modifications are introduced for NOICE: (i) the Arctic basin is not included (i.e., the model domain extends from the south pole to only $75^{\circ} \mathrm{N}$ ), and (ii) the emissivities for outgoing longwave radiation at the top of the atmosphere are reduced to warm up the southern polar region. The latter modification is done by superimposing on the emissivity of outgoing longwave radiation (Appendix C), a small negative anomaly, whose absolute value linearly increases from 0 at $40^{\circ} \mathrm{S}$ to 0.07 at the south pole. 


\subsection{Milankovitch forcing}

We use the algorithm of Berger (1978) and orbital parameters of Berger and Loutre (1991) to compute insolation values for the interval 5-3 Myr BP. Eccentricity cycles only change the annual global mean insolation by less than $0.2 \%$ (i.e., less than $1 \mathrm{~W} \mathrm{~m}^{-2}$ ). However, eccentricity has an important effect on the seasonality of insolation by modulating the intra-annual insolation changes associated with precession of the equinoxes. This precession amplifies or dampens the seasonal cycle of insolation without modifying the annual mean insolation. These changes in the amplitude of the seasonal cycle of insolation are in antiphase between the Southern and Northern Hemispheres. On an annual mean basis, obliquity modifies the low-to-high latitude insolation contrast without changing the global mean insolation. Thus, changes in annual mean insolation are in antiphase between tropical and polar regions, and the phase change occurs near $43^{\circ} \mathrm{S}$ and $43^{\circ} \mathrm{N}$.

\section{Equilibrium solution (modern climate)}

The ability of the model to simulate modern climate observations is assessed. Variables averaged over the last $100 \mathrm{yr}$ of a solution of the model version used for experiment ICE are used for the comparison.

The annual mean streamfunction in each ocean basin is shown in Fig. 2a. The maximum overturning in the North Atlantic Ocean below a depth of $500 \mathrm{~m}$ is about $15.5 \mathrm{~Sv}(1 \mathrm{~Sv}=$ $10^{6} \mathrm{~m}^{3} \mathrm{~s}^{-1}$ ). This agrees with the net zonally averaged northward transport of about $17 \mathrm{~Sv}$ of intermediate and surface water at $24^{\circ} \mathrm{N}$ in the Atlantic estimated from hydrographic data (Roemmich and Wunsch, 1985). In the Southern Ocean, the maximum overturning below a depth of $500 \mathrm{~m}$ is about $14 \mathrm{~Sv}$, which is consistent with a deep water formation rate estimated to approximately $15 \mathrm{~Sv}$ in this basin (Broecker et al, 1998). In the same basin, a wind-driven clockwise circulation cell known as the Deacon cell has a maximum overturning of about 24 $\mathrm{Sv}$. This circulation pattern, however, is an artifact that is reduced in high resolution models in isopycnal coordinates (Döös and Webb, 1994).

The global root mean square (rms) difference between the annual mean model and observed ocean temperature (salinity) (NODC, 1998) is $1.46^{\circ} \mathrm{C}(0.26)$. These values are within the range of values obtained for other ocean circulation models (Doney et al, 2004). The model can reproduce the observed latitude-depth temperature and salinity distributions, although there are differences (Figs. 2b-2e).

For surface air temperature, the global rms difference between annual means from the model and NCEP reanalysis (Kalnay et al, 1996) is $1.44^{\circ} \mathrm{C}$, which is smaller than the value reported by BHW99. A realistic seasonal cycle of air temperature is simulated by the model (Figs. 3a and 3b). In both polar regions, however, the amplitude of this cycle is larger in the model than in the climatology.

The amplitude of the simulated seasonal cycle of sea-ice area is comparable to the observed one in both hemispheres (Fig. 3c). However, the sea-ice area in the Northern Hemisphere is underestimated compared to observations. This is mainly because the model lacks several Arctic continental shelves, a large part of the Beaufort Sea, and other marginal seas where a significant part of the Arctic sea ice is present. The maximum sea-ice thickness during winter simulated by the model is about $4 \mathrm{~m}$ and $2 \mathrm{~m}$ in the Arctic and Southern Oceans, respectively.

Overall, although model-observation differences exist, the model is able to reproduce a climatic state that resembles the modern one. Below, the response of this model to timedependent Milankovith forcing between 5-3 Myr ago is explored. 


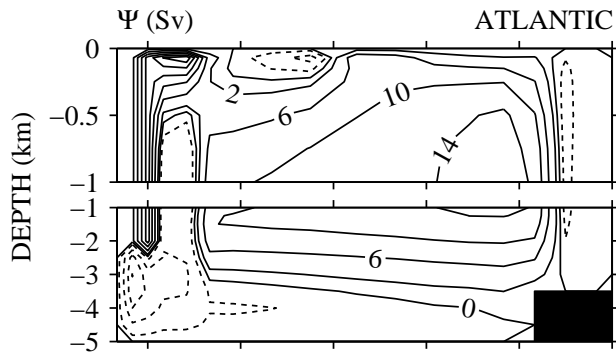

$T\left({ }^{\circ} \mathrm{C}\right):$ MODEL

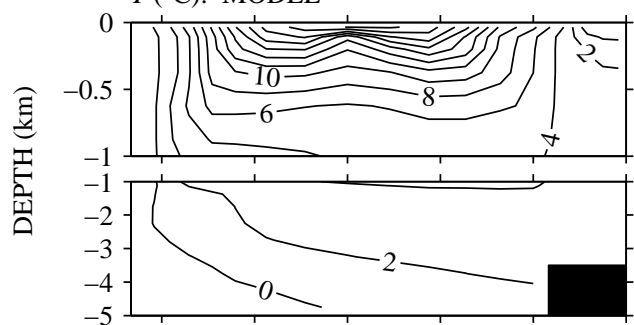

$T\left({ }^{\circ} \mathrm{C}\right)$ : LEVITUS 98

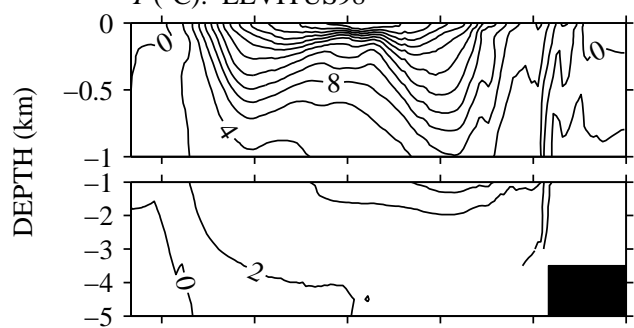

$S$ : MODEL

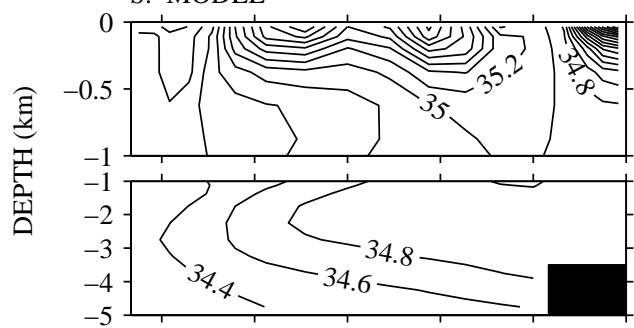

$S$ : LEVITUS98

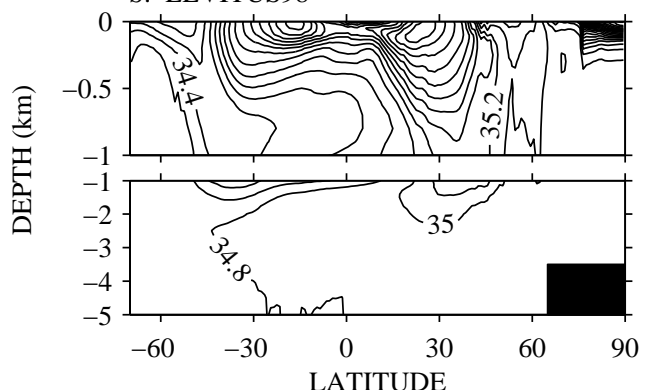

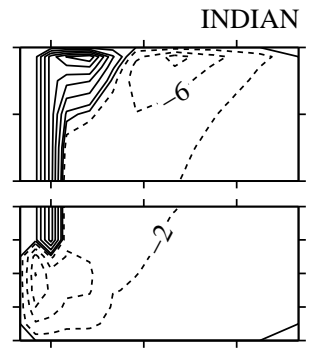

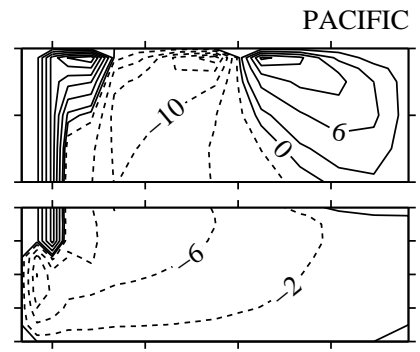

(a)
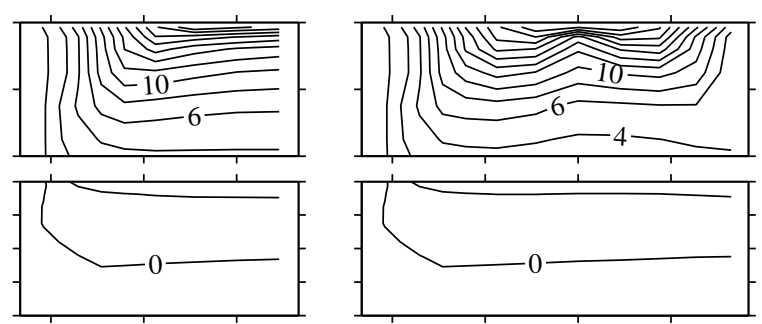

(b)
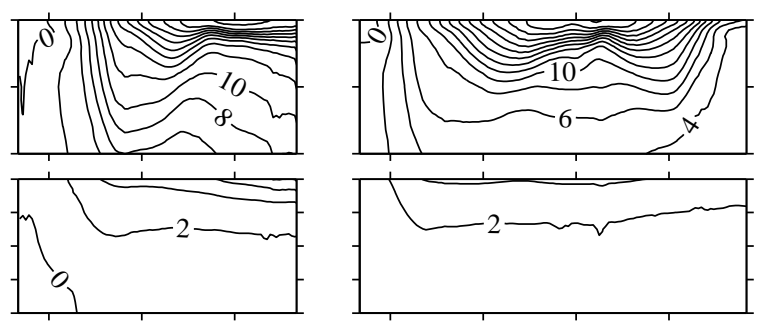

(c)
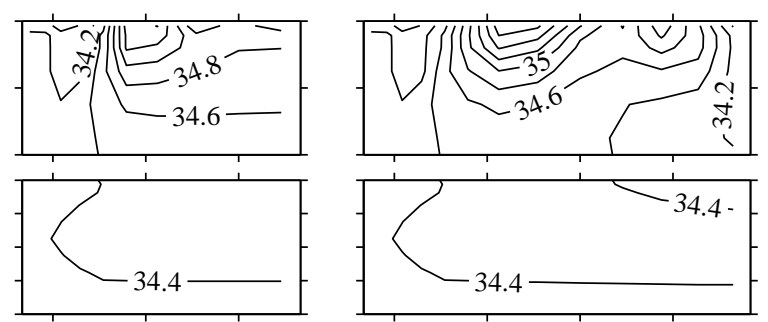

(d)
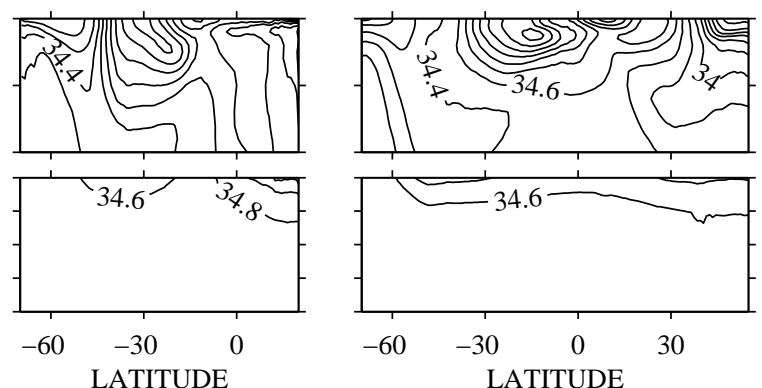

(e)

Fig. 2 Latitude-depth distributions of zonal and annual means of (a) streamfunction, (b)-(c) temperature, and (d)-(e) salinity. Model outputs averaged over the last $100 \mathrm{yr}$ of the modern climate equilibrium solution are shown in (a), (b), and (d). Climatological distributions of annual mean temperature and salinity from NODC (1998) are shown in panels (c) and (e), respectively. In (a), solid (dashed) contours show clockwise (counterclockwise) circulation. The contour interval for the streamfunction is $2 \mathrm{~Sv}$ for values between -2 and $2 \mathrm{~Sv}$, and it is $4 \mathrm{~Sv}$ otherwise. For temperature (salinity), the contour interval is $2^{\circ} \mathrm{C}(0.2)$. 


\section{Time-dependent solutions (5-3 Myr BP)}

In this section, results from the two numerical experiments (NOICE and ICE) are described. Emphasis is put on the response of air temperature $\left(T_{a}\right)$, ocean temperature $(T)$, sea-ice area (SIA), and sea-ice volume (SIV) to Milankovitch forcing. We consider annual means of these variables unless noted otherwise.

\subsection{Spatial patterns of temperature responses}

To elucidate these patterns we perform a principal component analysis (PCA). For a given model variable $x$, we denote the $\mathrm{k}^{\text {th }}$ component as $\mathrm{Ck}(x)$. The percentage of total variance accounted for a component decreases as $\mathrm{k}$ increases.

In general, the PCA results from NOICE and ICE are similar. Therefore, the description of a given component $\mathrm{Ck}(x)$ given below holds for both solutions unless noted otherwise.

\subsubsection{Air temperature}

$\mathrm{C} 1\left(T_{a}\right)(71 \%$ and $86 \%$ of total variance in NOICE and ICE, respectively) consists of a standing oscillation whereby air temperature falls and rises in antiphase between low and high latitudes at the obliquity frequency with two nodal points near $40^{\circ} \mathrm{S}$ and $40^{\circ} \mathrm{N}$ (Figs. $4 \mathrm{a}$ and 5a). In $\mathrm{C} 2\left(T_{a}\right)$ (23\% and $\left.11 \%\right)$, temperature changes are in antiphase between two regions of large variability at mid latitudes where air temperature anomalies oscillate at precessional frequencies (Figs. $4 \mathrm{~b}$ and $5 \mathrm{~b}$ ). $\mathrm{C} 3\left(T_{a}\right)(5 \%$ and $2 \%$ ) is dominated by eccentricity temperature cycles, although small amplitude precessional cycles are also present (Fig. 5c). It has a monopole structure, i.e., temperature changes are in phase across most latitudes (Fig. 4c).

\subsubsection{Ocean temperature}

The leading component $\mathrm{C} 1(T)(51 \%$ and $54 \%)$ mainly oscillates at precessional frequencies (Figs. 6a, 6b, and 7a).

A subsurface region of large variability is in the upper $500 \mathrm{~m}$ north of $45^{\circ} \mathrm{N}$ in the Atlantic Ocean, where ocean convection takes place in the model (Figs. 6a and 6b). A significant downward extension (to a depth of $3 \mathrm{~km}$ ) of these subsurface temperature cycles is observed in the northern North Atlantic (Figs. 6a and 6b).

In contrast to $\mathrm{C} 1(T), \mathrm{C} 2(T)(40 \%$ and $30 \%)$ is characterized by obliquity cycles (Fig. $7 \mathrm{~b})$. Near the sea surface, the spatial pattern and time evolution of $\mathrm{C} 2(T)$ resemble the ones of $\mathrm{C} 1\left(T_{a}\right)$ (Figs. $4 \mathrm{a}, 6 \mathrm{c}, 6 \mathrm{~d}, 5 \mathrm{a}$, and 7b). In NOICE (ICE), the variability of $\mathrm{C} 2(T)$ is large (small) below $3 \mathrm{~km}$ depth in all basins (Figs. 6c and 6d).

The time evolution of $\mathrm{C} 3(T)$ (5\% for both NOICE and ICE) is quite noisy but it contains a clear eccentricity signal (Fig. 7c). Its spatial structure largely resembles a monopole pattern, i.e., temperature changes that are in phase across most of the ocean (Figs. 6e and 6f). 

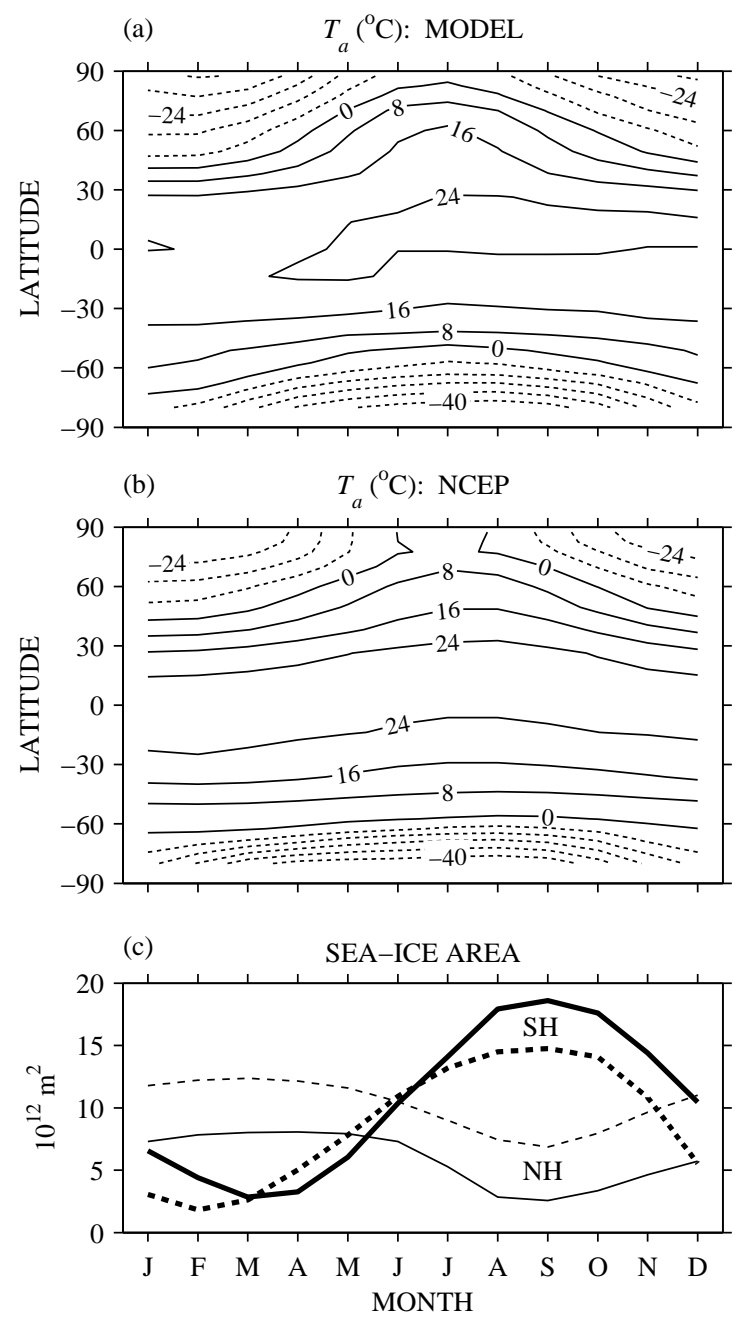

Fig. 3 Monthly mean surface air temperature from (a) the model and (b) the NCEP reanalysis (Kalnay et al, 1996) as a function of latitude and month of the year. Panel (c) shows the seasonal cycle of sea-ice area in the Northern (thin lines) and Southern (thick lines) Hemispheres as simulated by the model (solid lines) and from the climatologies of Walsh (1978) and Zwally et al (1983) (dashed lines). All the model variables are averages for the last $100 \mathrm{yr}$ of a modern climate equilibrium solution.

\subsection{Sea-ice area and volume (experiment ICE)}

It is instructive to compare the simulated SIA and SIV with integrated summer energy as defined by Huybers (2006):

$$
J=\int_{P} Q_{S W} \beta d t
$$

where $P$ is the length of the year and $Q_{S W}$ the daily insolation. $\beta$ is equal to $1(0)$ when $Q_{S W}>Q_{T}\left(Q_{S W}<Q_{T}\right)$, where $Q_{T}$ is a threshold insolation value. Huybers and Tziperman 
(a) $\mathrm{C} 1\left(T_{a}\right), \operatorname{NOICE}(71 \%), \operatorname{ICE}(86 \%)$

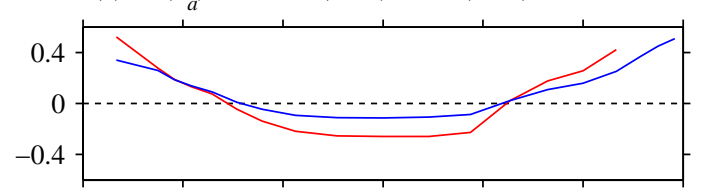

(b) $\mathrm{C} 2\left(T_{a}\right), \operatorname{NOICE}(23 \%), \operatorname{ICE}(11 \%)$

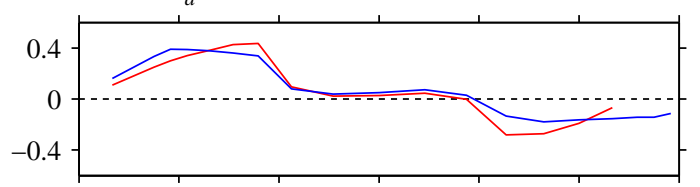

(c) $\mathrm{C} 3\left(T_{a}\right), \operatorname{NOICE}(5 \%), \operatorname{ICE}(2 \%)$

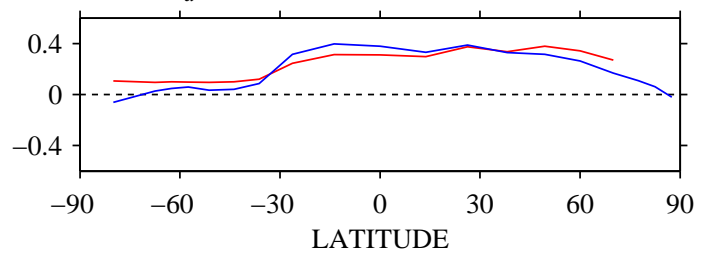

Fig. 4 Spatial patterns of the first three principal components of $T_{a}$. Results for solution NOICE (red) and ICE (blue) are shown. For each solution, the percentage of total variance explained by a given component is shown within parentheses.

(2008) give a detailed description of how $J$ depends on $Q_{T}$ and latitude. Note that poleward of $60^{\circ} \mathrm{N}$ and $60^{\circ} \mathrm{S}$ and for $Q_{T} \leq 350 \mathrm{~W} \mathrm{~m}{ }^{-2}, J$ mainly depends on obliquity.

The time series of annual mean SIA and SIV nearly mirror those of $J$, i.e., there is more ice when integrated summer energy is low and vice versa (Figs. $8 \mathrm{~b}$ and $8 \mathrm{c}$ ). Thus, obliquity cycles are dominant in the time series of SIA and SIV (Fig. 8). In both polar regions, this response of annual mean SIA and SIV to $J$ also holds for summer minimum SIA and SIV, as well as for winter maximum SIV (Figs. 8b and 8c). In the Southern Hemisphere, variations in winter maximum SIA are noisy but they tend to follow changes in annual mean SIA (Fig. 8b). On the other hand, the winter maximum SIA in the Northern Hemisphere remains approximately constant (Fig. 8b).

\section{Discussion}

\subsection{Air temperature}

If annual mean air temperature $\left(T_{a}\right)$ simply follows annual mean insolation, then the time series of $T_{a}$ will be dominated by obliquity cycles that will be in antiphase between low and high latitudes with a phase change near $43^{\circ} \mathrm{S}$ and $43^{\circ} \mathrm{N}$. This is what the leading mode $\mathrm{C} 1\left(T_{a}\right)$ shows in both NOICE and ICE (Figs. 5a and $4 \mathrm{a}$ ). The spatio-temporal variability of this mode is also observed in the time series of $T_{a}$ anomalies at different latitudes (Figs. $9 \mathrm{~b}$ and $9 \mathrm{c})$.

The time series of $T_{a}$ anomalies from both solutions also confirm the presence of weak variability at precessional frequencies in the midlatitudes (Figs. 9b and 9c), which is char- 


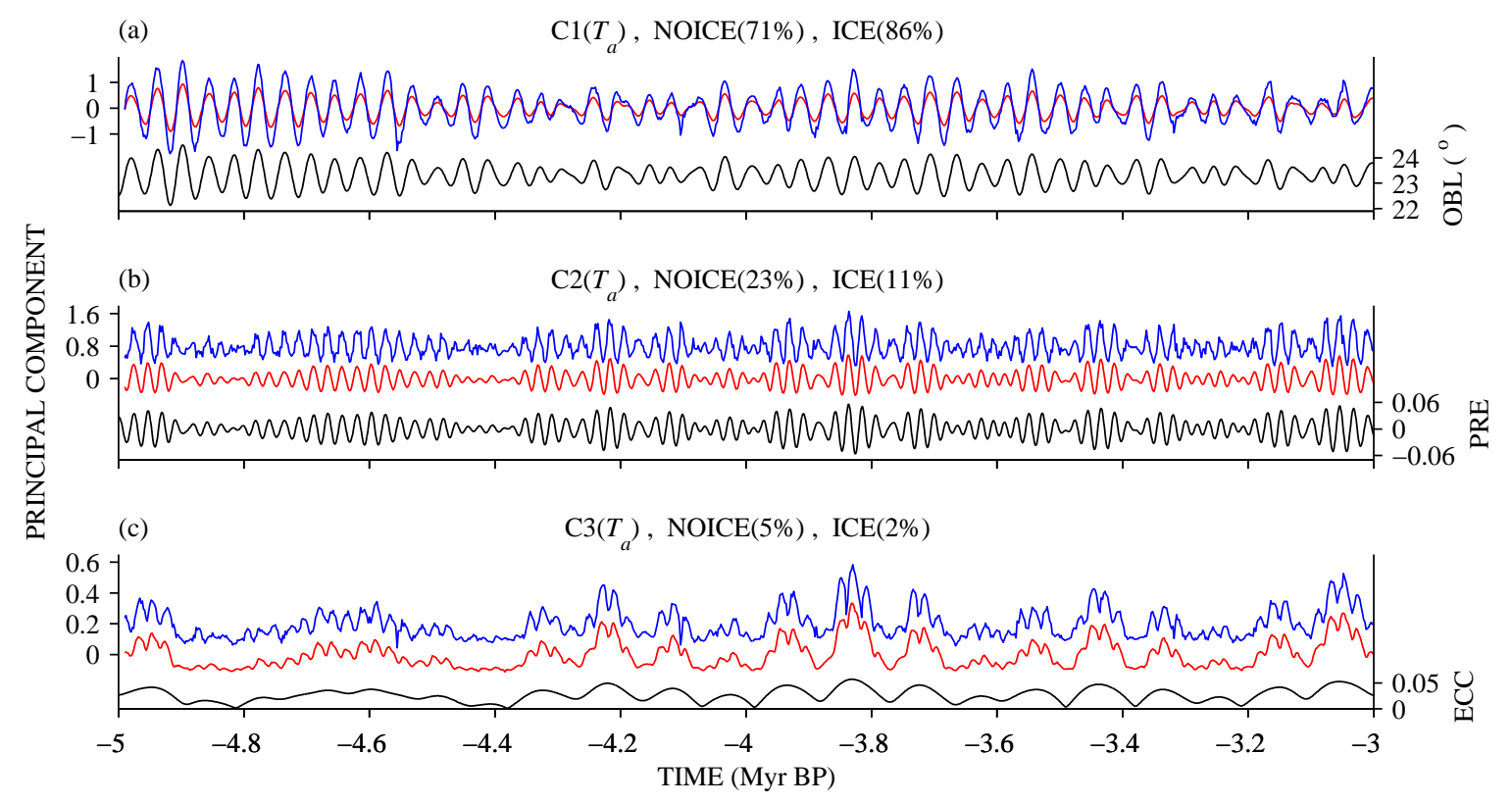

Fig. 5 Time series of the first three principal components of $T_{a}$ from solution NOICE (red) and ICE (blue). For a better visualization, an offset of $+0.8(+0.2)$ is added to the second (third) principal component corresponding to ICE. The percentage of total variance explained by each component is indicated within parenthesis. The time series of obliquity (OBL), climatic precession parameter (PRE), and eccentricity (ECC) are also presented in (a), (b), and (c), respectively.

acteristic of $\mathrm{C} 2\left(T_{a}\right)$ (Figs. 5b and $4 \mathrm{~b}$ ). This response of annual mean air temperature to precession suggests that the sensitivity of daily average air temperature to insolation changes is greater in a particular season than during the rest of the year. (At any latitude, precession modifies the seasonal cycle of insolation without changing the annual mean insolation.)

In NOICE and ICE, a very weak response of $T_{a}$ to eccentricity is revealed by the PCA. This is not surprising since eccentricity changes only cause very small variations in the annual mean insolation. Also, the monopole structure of $\mathrm{C} 3\left(T_{a}\right)$ is consistent with eccentricity changes that simultaneously increase or decrease the annual mean insolation at all latitudes.

\subsection{Ocean circulation and temperature}

The ocean circulation shows only very small changes in the solutions NOICE and ICE. Variations in North Atlantic overturning (not shown) are less than $1 \mathrm{~Sv}$ in both solutions, which is consistent with the results of BHW99. Thus, deep water of northern origin (NDW) and deep water of southern origin (SDW) are always present in NOICE and ICE. NDW is formed between $43.8^{\circ} \mathrm{N}$ and $75^{\circ} \mathrm{N}$ in the North Atlantic, and it is mainly found in the Atlantic Ocean between 1-3 km depth. The model forms SDW between $60^{\circ} \mathrm{S}$ and $70^{\circ} \mathrm{S}$, and this water mass is found below $3 \mathrm{~km}$ in every basin (except the Arctic Ocean). 

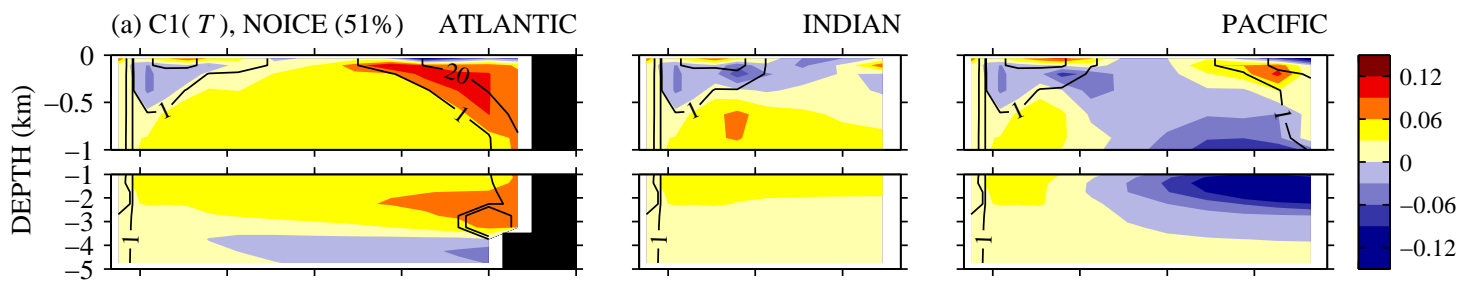

(b) $\mathrm{C} 1(T), \operatorname{ICE}(54 \%)$
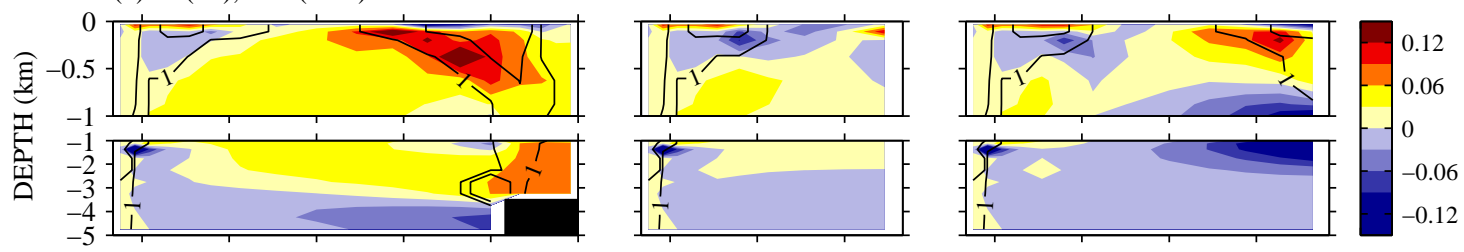

(c) $\mathrm{C} 2(T), \operatorname{NOICE}(40 \%)$
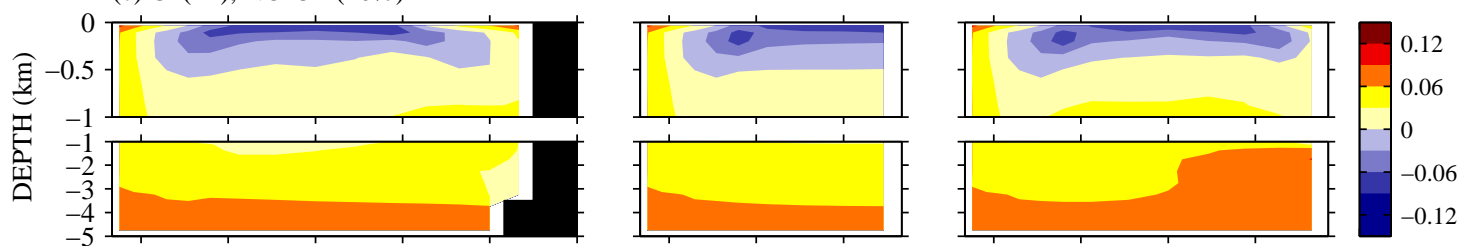

(d) $\mathrm{C} 2(T), \operatorname{ICE}(30 \%)$
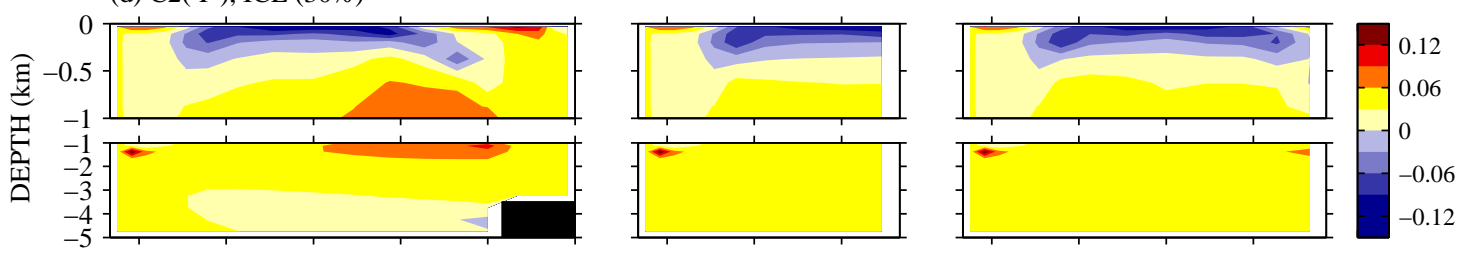

(e) C3( $T)$, NOICE $(5 \%)$
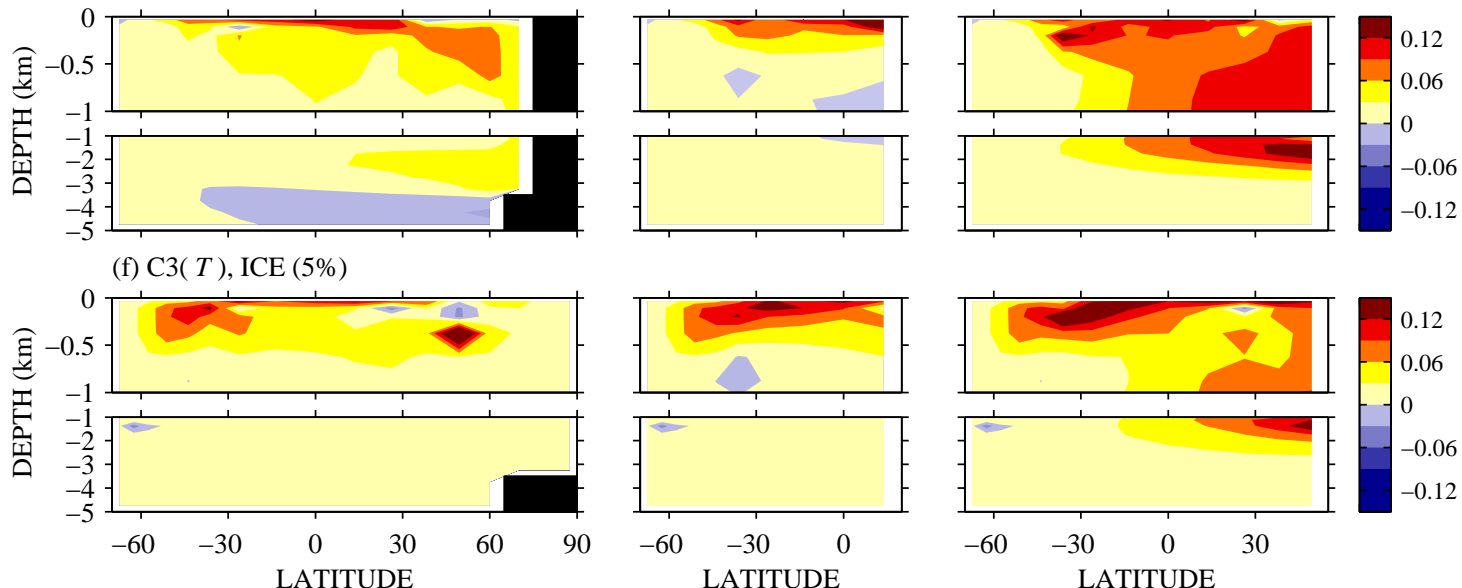

Fig. 6 Spatial patterns of the first three principal components of $T$ from NOICE and ICE solutions. The percentage of total variance explained by each component is shown within parentheses. Black contours in (a) and (b) are the 1 and 20 isolines of the annual mean convective index averaged over the interval 5-3 Myr BP. In each ocean grid cell and at each ocean time step, the convective index is defined as equal to $100(0)$ if convection does (not) occur. 


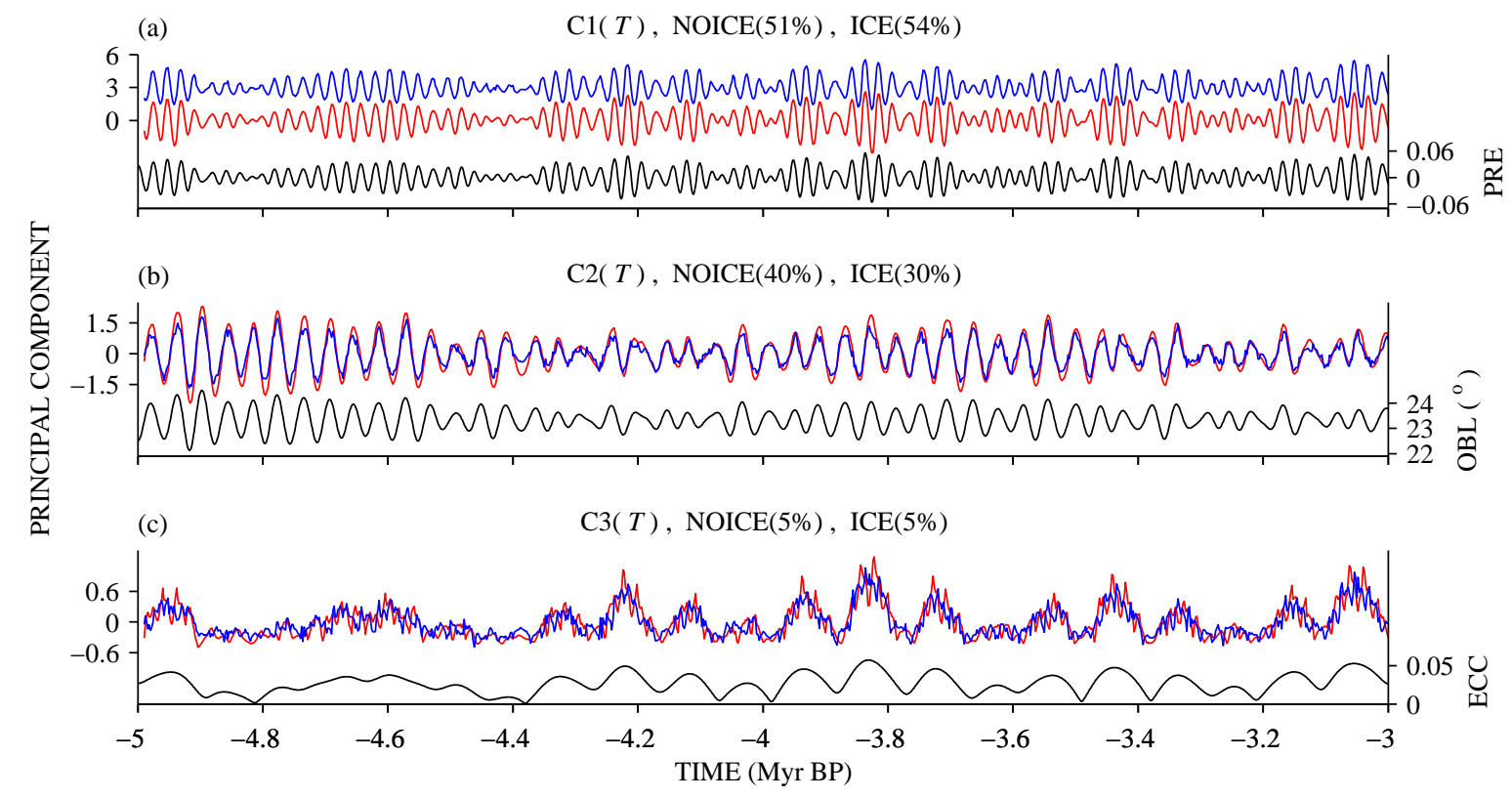

Fig. 7 As in Fig. 5 but for the first three principal components of $T$. In panel (a), an offset of +3 is added to the first principal component corresponding to ICE for better visualization. Time series of the climatic precession parameter (PRE), obliquity (OBL), and eccentricity (ECC) are shown in (a), (b), and (c), respectively.

\subsubsection{Response to precession}

Figure 10c shows the presence of precessional temperature cycles at a particular location in the Atlantic Ocean (43. $8^{\circ} \mathrm{N}-55^{\circ} \mathrm{N}, 200-250 \mathrm{~m}$ depth). There, changes in heat fluxes associated with winter convection are negatively correlated with changes in autumn-winter average insolation that are dominated by precessional cycles (Figs. 10a and 10b). Because of these changes in convective heat flux, the subsurface ocean layers lose more (less) heat when autumn-winter insolation is low (high). Thus, temperature below the mixed layer is minimum (maximum) when autumn-winter insolation is also minimum (maximum) (Fig. 10c). In NOICE and ICE experiments, this mechanism explains the large variability of $\mathrm{C} 1(T)$ that occurs in the Atlantic between $45^{\circ} \mathrm{N}-65^{\circ} \mathrm{N}$ and $70-500 \mathrm{~m}$ depth, where convection is active (Figs. 6a and 6b). Because NDW is formed in this region, precessional temperature cycles are introduced into the deep ocean via this water mass (Fig. 11b). This result is consistent with the response of global mean ocean temperature to winter insolation found by BHW99 (see their section 5.a).

Compared to NDW, the SDW temperature exhibits small variability at precessional frequencies (Fig. 11c). Indeed, precessional cycles of autumn-winter average insolation are insignificant in the region where SDW is formed (i.e., between $60^{\circ} \mathrm{S}$ and $70^{\circ} \mathrm{S}$ ). Consequently, there is no significant response of SDW temperature to these insolation cycles. 


\subsubsection{Response to obliquity and eccentricity}

In NOICE and ICE, obliquity cycles of ocean temperature near the surface are in antiphase between low and high latitudes with a phase reversal near $40^{\circ} \mathrm{N}$ and $40^{\circ} \mathrm{S}$ (Figs. $6 \mathrm{c}$ and $6 \mathrm{~d})$. This behavior can be interpreted similarly as for the obliquity cycles of air temperature (Sect. 5.1).

According to the PCA results for both solutions, while near surface obliquity-driven temperature changes can extend down to the seafloor in polar regions, they only extend downward by a few hundred meters at low latitudes. In the upper tropical oceans, a strong stratification confines the effect of insolation changes on temperature to the upper $500 \mathrm{~m}$. This vertical extent is determined by vertical advection (driven by wind and/or thermohaline surface forcings) and vertical diffusion. On the other hand, upper ocean temperature variations at high latitudes can reach the deep ocean because deep water is formed at these latitudes.

As for air temperature, changes in ocean temperature at eccentricity frequencies are very small. The absence of a significant response of ocean temperature to eccentricity in our model is in agreement with BHW99.

\subsection{Magnitude of temperature responses}

In this section, we compare the magnitude of temperature changes from our warm-climate experiments (i.e, no land ice) with those derived from paleoclimate records for the warm Pliocene climate.

Annual mean air and ocean temperature changes are smaller than $2^{\circ} \mathrm{C}$ in NOICE and ICE. This weak response is consistent with variations of deep-ocean bottom-water temperature (BWT) estimated from magnesium to calcium ratios $(\mathrm{Mg} / \mathrm{Ca})$ in fossil ostracodes. Cronin et al (2005) estimated BWTs for the 3.29-2.97 Myr BP interval (middle Pliocene) in the South and North Atlantic Oceans that are about $1-1.5^{\circ} \mathrm{C}$ warmer than modern values. Dwyer et al (1995) estimated peak-to-trough BWT changes of $1.5^{\circ} \mathrm{C}$ between 3.2 and 2.8 Myr BP (late Pliocene) in the North Atlantic Ocean. Note that these BWT changes are smaller than the glacial-to-interglacial changes of about $4.5^{\circ} \mathrm{C}$ derived from North Atlantic ostracode $\mathrm{Mg} / \mathrm{Ca}$ data for the last two glacial cycles (Dwyer et al, 1995).

\subsection{Sea-ice area and volume}

According to the ICE solution, annual mean sea-ice conditions in both polar regions are mostly controlled by the integrated summer energy $J$, which mainly depends on obliquity. That is, sea ice mainly responds to the insolation integrated only over summer days in which it is higher than a threshold value. This is because ice melting mostly occurs when this condition for summer insolation is satisfied. For instance, when summer insolation is greater than a certain threshold, the surface ice temperature exceeds the melting point, and ablation occurs at the ice surface. Similarly, rates of ablation at the ice bottom and lateral melting are only significant when summer insolation exceeds a threshold.

In general, the long-term variability of seasonal extrema in sea-ice conditions (e.g., summer minimum sea-ice volume) is similar to that of annual mean conditions and therefore can be interpreted as above. However, changes in maximum sea-ice area during boreal winter 
(a)

ORBITAL PARAMETERS

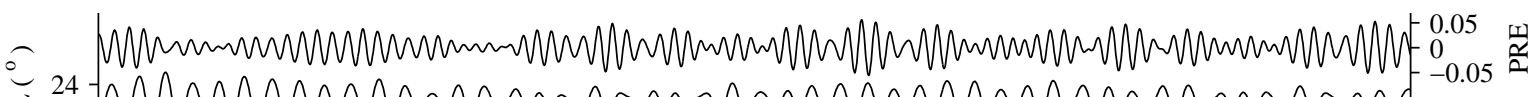

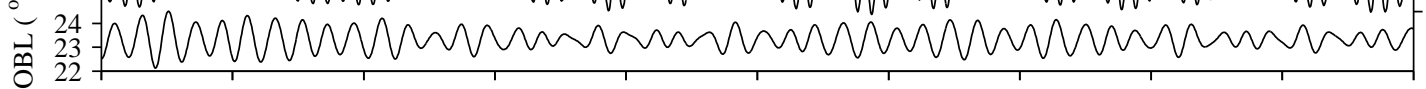

(b)

SEA-ICE AREA

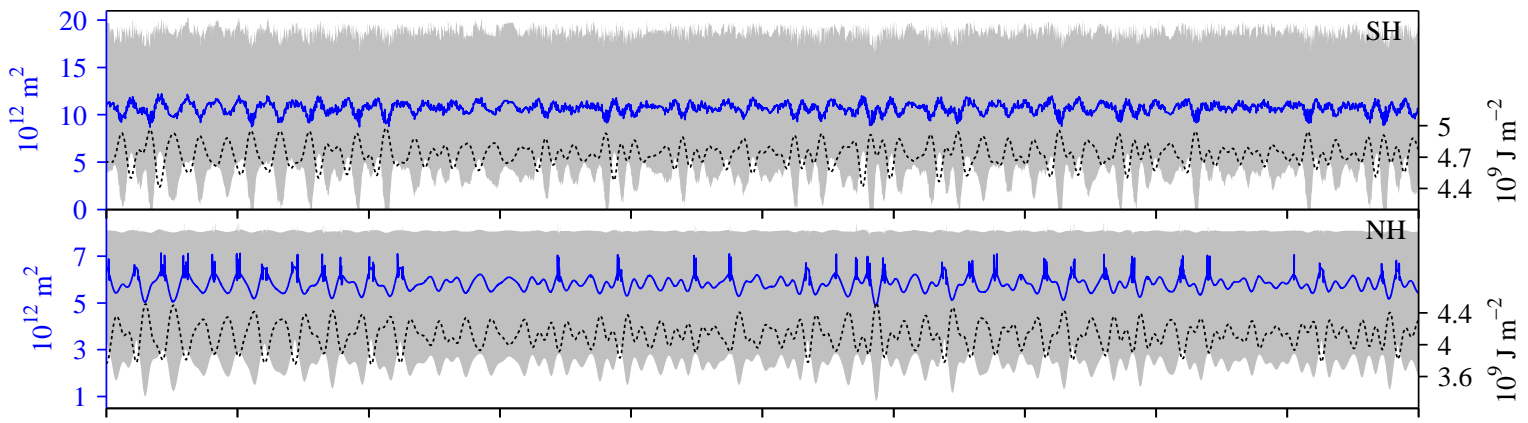

(c)

SEA-ICE VOLUME

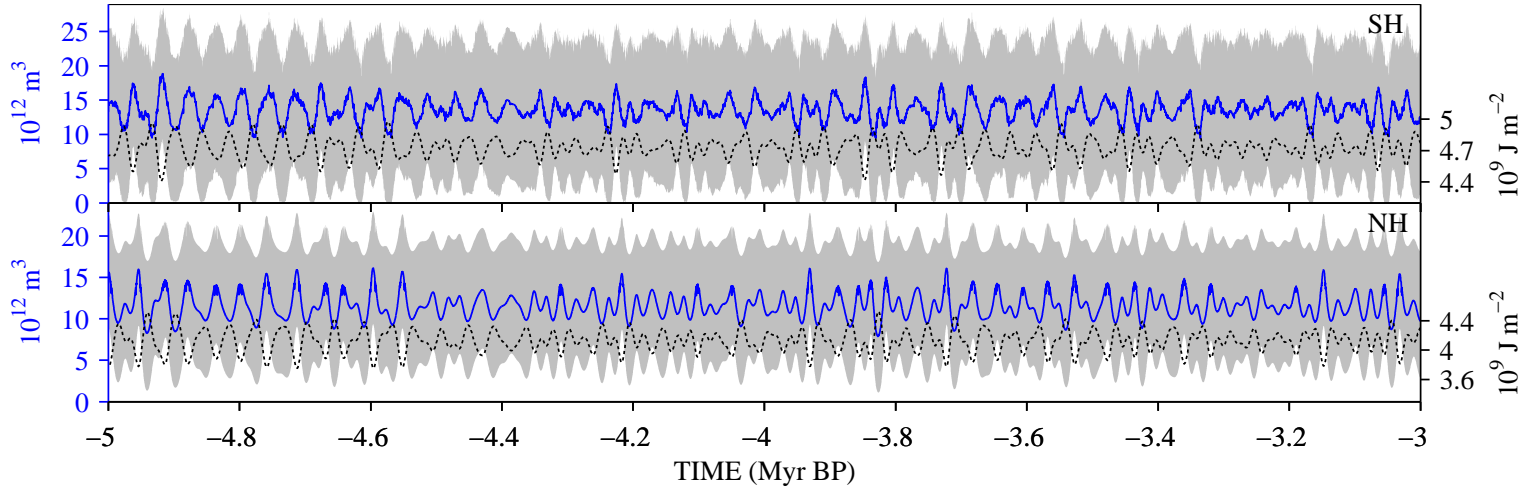

Fig. 8 Time series of (a) obliquity and climatic precession parameter, (b) annual mean sea-ice area (blue), and (c) annual mean sea-ice volume (blue). In panels (b) and (c), results for the Northern (NH) and Southern (SH) Hemispheres are shown. The upper and lower limits of the gray region in (b) and (c) correspond to the winter maximum and summer minimum values, respectively. For the $\mathrm{SH}(\mathrm{NH})$, the dashed lines show integrated summer insolation $J$ calculated with $Q_{T}=300(350) \mathrm{W} \mathrm{m}^{-2}$ at $65^{\circ} \mathrm{S}\left(85^{\circ} \mathrm{N}\right)$.

are very small because sea ice is confined in the nearly closed Arctic basin (i.e., the Arctic coastline imposes a limit on the expansion of sea-ice cover).

\subsection{Role of sea ice}

Here, we compare results from NOICE and ICE solutions to analyze the role of sea ice in the temperature responses to Milankovitch forcing. Note that this comparison is not made for the northern polar region because the Arctic basin is not included in NOICE (see section 2.2). 
(a)
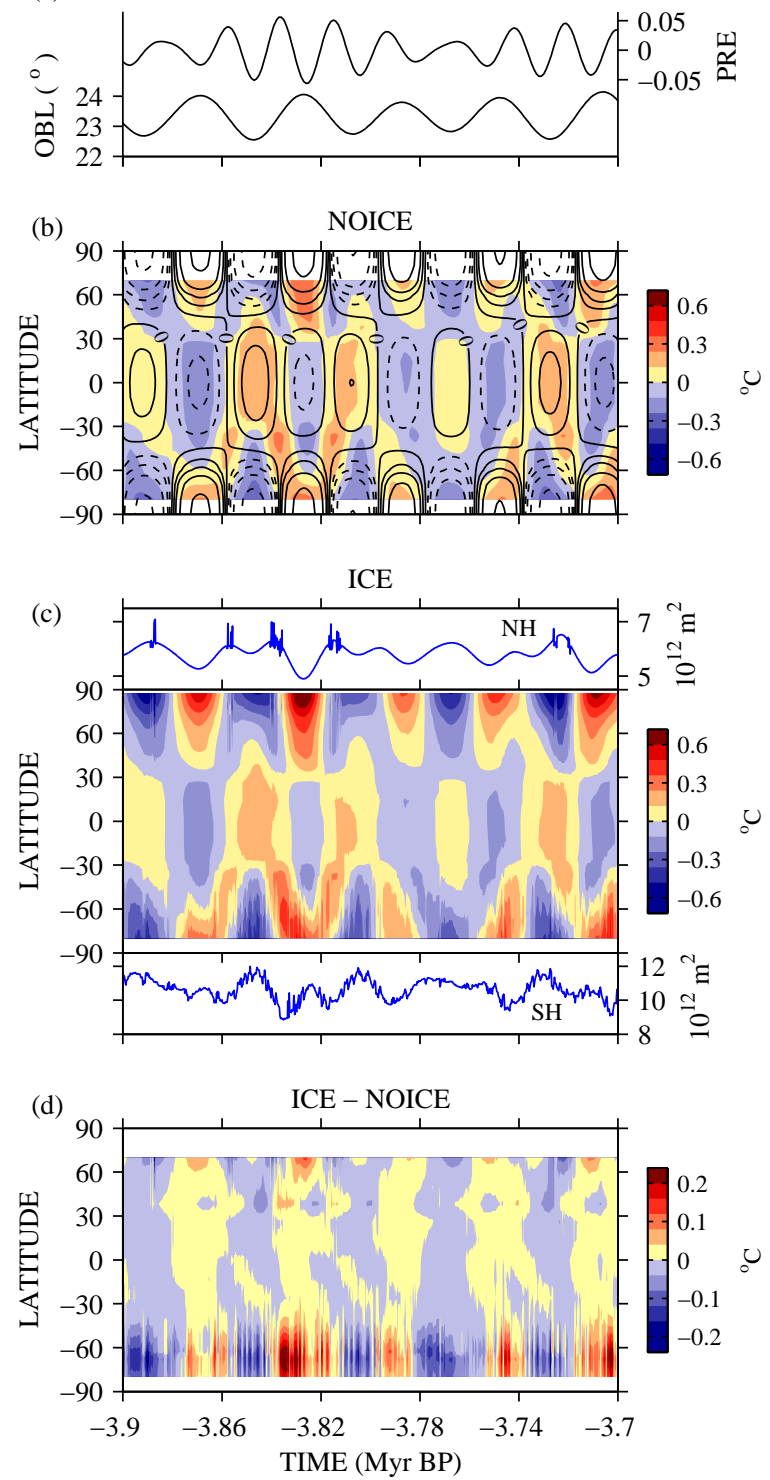

Fig. 9 (a) Time series of obliquity (OBL) and climatic precession parameter (PRE). Hovmöller diagrams of $T_{a}$ anomalies from (b) NOICE, (c) ICE, and (d) of the difference between ICE and NOICE. Solid (dashed) black contours in (b) show positive (negative) anomalies of annual mean insolation. Temperature and insolation anomalies are obtained by removing the time mean (of the interval 3.9-3.7 Myr BP) at every latitude. The contour interval for anomalies of annual mean insolation is $0.5 \mathrm{~W} \mathrm{~m}^{-2}$ for values between -1 and $1 \mathrm{~W}$ $\mathrm{m}^{-2}$, and it is $2 \mathrm{~W} \mathrm{~m}^{-2}$ otherwise. In (c), variations in Southern ( $\mathrm{SH}$ ) and Northern (NH) Hemisphere sea-ice area are also shown. 
(a)

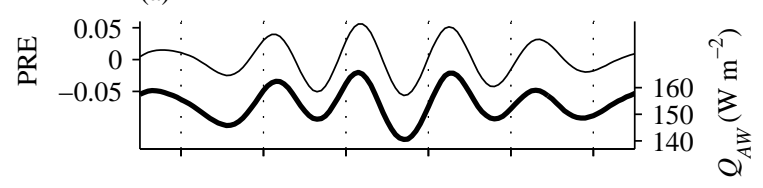

(b) $Q_{\text {conv }}\left(43.8^{\circ} \mathrm{N}-55^{\circ} \mathrm{N}\right)$

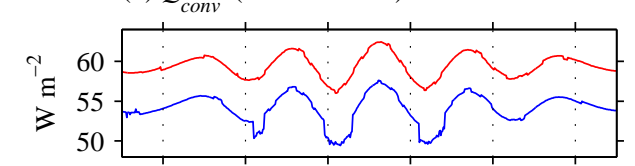

(c) $T\left(43.8^{\circ} \mathrm{N}-55^{\circ} \mathrm{N}, 200-250 \mathrm{~m}\right.$ depth $)$

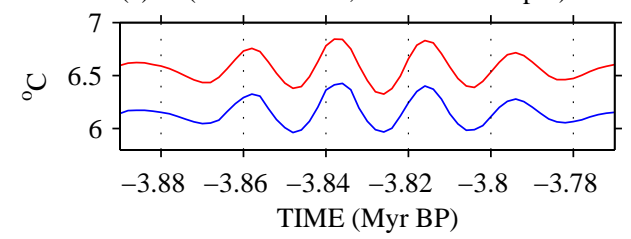

Fig. 10 (a) Climatic precession parameter (PRE, thin line) and autumn-winter average insolation at $50^{\circ} \mathrm{N}$ ( $Q_{A W}$, thick line). (b) Annual mean convective heat flux at a depth of $70 \mathrm{~m}$ and between $43.8^{\circ} \mathrm{N}-55^{\circ} \mathrm{N}$ in the Atlantic Ocean. (c) Annual mean ocean temperature at a North Atlantic grid cell. In (b) and (c), NOICE (ICE) results are shown by red (blue) lines. Values of autumn-winter average insolation are obtained by using the equinoxes as starting and end points of autumn-winter.

Sea ice has the effect of amplifying the obliquity cycles of air temperature in the polar region of the Southern Hemisphere (Fig . 9d). This effect is explained as follows. At high latitudes and when obliquity is large, an increased annual mean insolation tends to increase the air temperature, and an increased $J$ tends to decrease the sea-ice area (see sections 5.1 and 5.4). Changes with opposite sign occur when obliquity is small. These changes in air temperature and sea-ice area reinforce each other because of (i) the insulating effect of sea ice and (ii) the sea-ice albedo feedback.

As shown by PCA results for ocean temperature, sea ice has the effect of diminishing the obliquity temperature cycles below a depth of $3 \mathrm{~km}$ in all basins (compare Figs. $6 \mathrm{c}$ and 6d), where SDW is found. Time series of SDW temperature also show this filtering effect of sea ice (Fig. 11c). This effect is due to winter sea ice always keeping the water below the ice near the freezing point in regions where SDW forms in the ICE experiment (i.e., between $60^{\circ} \mathrm{S}$ and $\left.70^{\circ} \mathrm{S}\right)$.

In contrast to the Southern Hemisphere, the deep water formation sites of the North Atlantic Ocean are ice-free year-round in the ICE solution. Hence, the filtering effect of sea ice does not affect the temperature of NDW as shown by the PCA (Figs. 6c and 6d) and the time series of NDW temperature (Fig. 11b).

\subsection{Phase lag between forcing and responses}

Phase lags between insolation curves (e.g., $J$ and annual mean insolation) and model responses (e.g., annual mean sea-ice area and ocean temperature) at different Milankovitch frequencies are very small. This result is expected because the thermal response time of 
(a) ORBITAL PARAMETERS

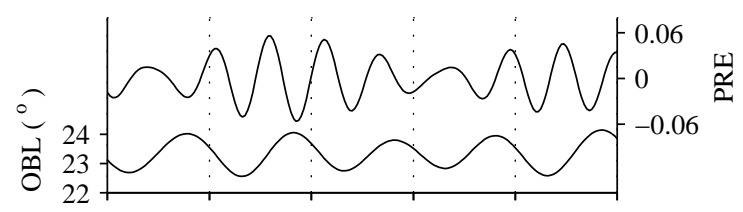

(b) NDW TEMPERATURE

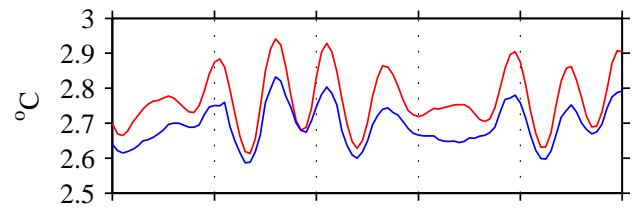

(c) SDW TEMPERATURE

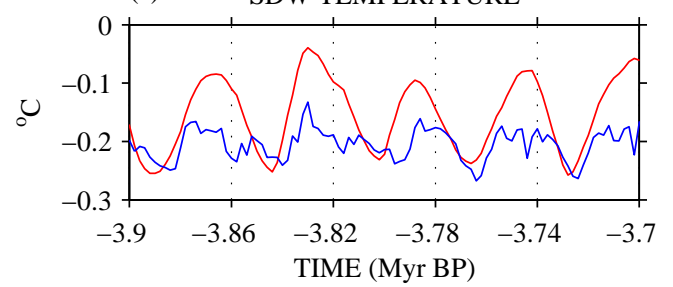

Fig. 11 (a) Variations in obliquity (OBL) and climatic precession parameter (PRE). Simulated variations in the temperature of deep water of northern (NDW) and southern (SDW) origin are shown in panels (b) and (c), respectively. Red (blue) lines are for NOICE (ICE). NDW temperature is computed as the average of annual mean ocean temperature between $1.5-3 \mathrm{~km}$ depth and $40^{\circ} \mathrm{S}-75^{\circ} \mathrm{N}$ in the Atlantic Ocean. SDW temperature is obtained as the average of annual mean ocean temperature below $3.5 \mathrm{~km}$ depth over the Global Ocean. NDW and SDW temperature values from NOICE are decreased by $1^{\circ} \mathrm{C}$ and $0.7^{\circ} \mathrm{C}$, respectively, for better visualization.

every component of the model is much smaller than any Milankovitch period. The largest response time in the model occurs in the deep ocean. It is about a few thousand years, which is very small compared to the shortest Milankovitch period (ca. $20 \mathrm{kyr}$ ).

\section{Conclusions}

The time-dependent response of climate to Milankovitch forcing for the time interval 5-3 Myr BP (i.e., early and middle Pliocene), when large continental ice sheets were small or absent on the major continents, is investigated using a zonally averaged ocean-atmospheresea ice model. Our major results are the following:

1. At most latitudes, annual mean surface air temperature mainly follows obliquity cycles of annual mean insolation. The response of annual mean ocean temperature is more complex. In the North Atlantic between 70-500 m depth and $45^{\circ} \mathrm{N}-65^{\circ} \mathrm{N}$, dominant precessional temperature cycles are generated as a truncated response of ocean convection to precessionally-driven autumn-winter insolation changes. As deep water is formed in this region, the subsurface ocean temperature variability at precessional frequencies can be transmitted to the deep Atlantic. In contrast, when sea ice is not included in the model, the temperature of deep water formed south of $60^{\circ} \mathrm{S}$ follows annual mean insolation at these 
latitudes, which mainly oscillates near the obliquity frequency. The magnitude of deep temperature changes as simulated by the model is consistent with bottom water temperature changes estimated from ostracode $\mathrm{Mg} / \mathrm{Ca}$ data for the Pliocene.

2. Sea ice acts as a time-integrator of summer insolation values greater than a certain threshold. Thus, changes in surface area and volume of sea ice are dominated by variations near the obliquity frequency in both polar regions. The changes in sea-ice conditions amplify the changes in air temperature in these regions and suppress the temperature variability in the deep water of southern origin. The first effect is due to the insulating effect of sea ice and the sea ice-albedo feedback. The second is due to the fact that sea ice keeps sea surface temperature near the freezing point in regions where deep water is formed in the Southern Ocean.

Finally, we emphasize that several simplifications are introduced in our model to increase its computational efficiency, which is needed for obtaining 2-Myr long solutions. Hence, our experiments should be repeated with more complex general circulation models to assess the significance of our results in the real world with more complete models. However, although general circulation models have a more detailed representation of climatic processes than in our model (e.g., atmospheric and ocean circulation), their computational cost is too high for long runs. Considering that this limitation would be overcome in the near future, we hope that this study provides a useful background for future studies based on more complete models of the climate system.

Acknowledgements We thank Marie-France Loutre, Eli Tziperman and Daniel Wright for their valuable inputs and two anonymous reviewers for their comments. This work was supported by an NSERC Discovery Grant awarded to L.A.M. We also thank GEC3 for a Network Grant. NODC (Levitus) World Ocean Atlas 1998 and NCEP Reanalysis Derived data provided by the NOAA/OAR/ESRL PSD, Boulder, Colorado, USA, from their web site at http://www.cdc.noaa.gov/.

\section{APPENDIX A: Model description}

\section{A.1 Ocean component}

The ocean component is the zonally averaged ocean circulation model of Wright and Stocker (1992). The parameters are given in Table A1. The governing equations are

$$
\begin{gathered}
\frac{1}{R \Delta \Lambda_{o}} \frac{\partial\left(c \Delta \Lambda_{o} \bar{v}\right)}{\partial s}+\frac{\partial \bar{w}}{\partial z}=0 \\
-2 s \Omega \bar{v}=-\frac{1}{\rho_{o} R c} \frac{\Delta p}{\Delta \Lambda_{o}}+\frac{\overline{\tau^{\lambda}}}{\rho_{o} \Delta z_{m}} \mathscr{H}\left(z+\Delta z_{m}\right), \\
2 s \Omega \bar{u}=-\frac{c}{\rho_{o} R} \frac{\partial \bar{p}}{\partial s}, \\
\frac{\partial \bar{p}}{\partial z}=-g \bar{\rho}(\bar{T}, \bar{S}, \bar{p}), \\
\frac{\partial \bar{T}}{\partial t}+\frac{1}{R \Delta \Lambda_{o}} \frac{\partial\left(c \Delta \Lambda_{o} \bar{v} \bar{T}\right)}{\partial s}+\frac{\partial(\bar{w} \bar{T})}{\partial z}= \\
\frac{1}{R^{2} \Delta \Lambda_{o}} \frac{\partial}{\partial s}\left(K_{H} \Delta \Lambda_{o} c^{2} \frac{\partial \bar{T}}{\partial s}\right)+\frac{\partial}{\partial z}\left(K_{V} \frac{\partial \bar{T}}{\partial z}\right)+q_{\text {conv }}^{T}+q_{i c e}^{T},
\end{gathered}
$$




$$
\begin{aligned}
& \frac{\partial \bar{S}}{\partial t}+\frac{1}{R \Delta \Lambda_{o}} \frac{\partial\left(c \Delta \Lambda_{o} \bar{v} \bar{S}\right)}{\partial s}+\frac{\partial(\bar{w} \bar{S})}{\partial z}= \\
& \frac{1}{R^{2} \Delta \Lambda_{o}} \frac{\partial}{\partial s}\left(K_{H} \Delta \Lambda_{o} c^{2} \frac{\partial \bar{S}}{\partial s}\right)+\frac{\partial}{\partial z}\left(K_{V} \frac{\partial \bar{S}}{\partial z}\right)+q_{c o n v}^{S}+q_{i c e}^{S}
\end{aligned}
$$

Here $(\overline{.})$ (dropped henceforth) designates a zonally averaged value, $(u, v, w)$ are the zonal, meridional and vertical velocity components, respectively, $p$ is the pressure, $\rho$ the density, $T(S)$ the potential temperature (salinity), $s(c)$ the sine (cosine) of latitude $(\phi), t$ the time, $z$ the vertical coordinate (equal to zero at the surface and negative downward), $\Delta \Lambda_{o}$ the basin angular width, $\Delta p$ the zonal pressure difference across the basin, $\Delta z_{m}$ the mixed layer thickness, $R(\Omega)$ the Earth's radius (angular velocity), $\rho_{o}$ a reference density, $g$ the acceleration of gravity, $\tau^{\lambda}$ the zonal component of wind stress, $\mathscr{H}$ the Heaviside step function $[\mathscr{H}(x)=0$ if $x \leq 0 ; \mathscr{H}(x)=1$ if $x>0$ ], $K_{H}\left(K_{V}\right)$ the horizontal (vertical) mixing coefficient, $q_{\text {conv }}^{T}\left(q_{\text {conv }}^{S}\right)$ the effect of vertical convection on $T(S)$, and $q_{\text {ice }}^{T}\left(q_{\text {ice }}^{S}\right)$ the effect of sea-ice volume changes on $T(S)$. The in situ density, $\rho$, is computed using a non-linear equation of state (Wright, 1997). Unstable stratification is removed using the convective scheme of Wright and Stocker (1992).

The closure scheme of Wright and Stocker (1991) is used for $\Delta p$ :

$$
\Delta p=-\varepsilon \Delta \Lambda_{o} \sin (2 \phi) \frac{\partial p}{\partial \phi}
$$

Here, $\varepsilon=\varepsilon_{c} \pi /\left(3 \Delta \Lambda_{o}\right)$ where $\varepsilon_{c}$ is a closure parameter. Although a more elaborate closure is available (Wright et al 1995; Wright et al 1998), expression (A7) is used here for simplicity. Based on ocean general circulation model results, Wright and Stocker (1991) suggested $\varepsilon_{c}$ values of $0.3-0.6$. Here, $\varepsilon_{c}=0.6$ between $55^{\circ} \mathrm{S}-75^{\circ} \mathrm{N}$, where meridional boundaries exist (Fig. 1). Although land masses are absent between $70^{\circ} \mathrm{S}-55^{\circ} \mathrm{S}$, several subsurface ridges do exist in the real Southern Ocean. The zonal pressure differences supported by these ridges are presumably important in transporting geostrophically Antarctic Bottom Water northward. Here, $\varepsilon_{c}$ $=0.6\left(\varepsilon_{c}=0\right)$ is used for $z \leq-2 \mathrm{~km}(z>-2 \mathrm{~km})$ to parameterize the dynamical effect of three equally spaced meridional ridges in the Southern Ocean between $70^{\circ} \mathrm{S}-55^{\circ} \mathrm{S}$ and below a depth of $2 \mathrm{~km}$ (Wright and Stocker, 1992). In contrast to the Southern Ocean, meridional ridges in the Arctic Ocean are not represented, and $\varepsilon=$ $10^{-4}$ is applied north of $75^{\circ} \mathrm{N}$.

The boundary conditions are as follows. A condition of no normal flux is used for heat, salt and momentum at the meridional boundaries and seafloor, monthly climatological means of $\tau^{\lambda}$ (Kalnay et al, 1996) are applied at the sea surface, and two types of surface boundary condition for $T$ and $S$ are used:

$$
\begin{gathered}
-\left.K_{v} \frac{\partial T}{\partial z}\right|_{z=0}=\left\{\begin{array}{l}
\Delta z_{m}\left(T_{m}-T^{*}\right) / \tau_{T}, \\
{\left[(1-A) Q^{O A}+A Q^{O I}\right] /\left(\rho_{o} C_{p o}\right),}
\end{array}\right. \\
-\left.K_{v} \frac{\partial S}{\partial z}\right|_{z=0}=\left\{\begin{array}{l}
\Delta z_{m}\left(S_{m}-S^{*}\right) / \tau_{S}, \\
F_{S}^{*} .
\end{array}\right.
\end{gathered}
$$

The restoring conditions are used to spin up the ocean model, whereas the flux conditions are used when coupling this component to the atmosphere and sea-ice components. Thus, $\tau_{T}\left(\tau_{S}\right)$ is a restoring time for temperature (salinity), the subscript $m$ is used for the mixed layer, $T^{*}\left(S^{*}\right)$ is a monthly climatological mean of $T_{m}\left(S_{m}\right)$ at a depth of $30 \mathrm{~m}$ (NODC, 1998), $A$ the sea-ice concentration (defined in section A.3), $Q^{O A(I)}$ the ocean-air(sea ice) heat flux, $C_{p o}$ the specific heat of seawater at constant pressure, and $F_{S}^{*}$ a virtual salt flux diagnosed from the restoring boundary condition for $S$ at the end of the ocean spinup.

The numerical schemes (finite differences) are as follows. Equations (A5) and (A6) are solved with the scheme of Smolarkiewicz (1983) for the advective terms, a second-order centered-in-space scheme for the diffusive terms, and a first-order Euler scheme for the time derivatives. After the fields of $T$ and $S$ are updated, the density field is computed and the velocity field is diagnosed from the fields of density and wind stress using equations (16) and (17) of Wright and Stocker (1992). When the ocean model is integrated under restoring boundary conditions, a time step of $365 / 72 \approx 5$ days is used. When flux boundary conditions are applied (i.e., in a coupled run), Eqns. (A5) and (A6) for the ocean mixed layer and for the rest of the ocean domain are integrated asynchronously (Wright and Stocker, 1993). In the latter case, a time step of $365 / 216 \approx 1.7(365 / 72 \approx 5)$ days is used in (out of) the ocean mixed layer.

\section{A.2 Atmospheric component}

The Energy Balance Model (EBM) of Stocker et al (1992) is extended to take into account: (i) different albedo values for different types of surfaces (ocean, land, sea ice, and top of the atmosphere), (ii) the heat exchange 
Table A1 Ocean parameters.

\begin{tabular}{|c|c|c|}
\hline$\Omega$ & Earth's angular velocity & $7.27 \times 10^{-5} \mathrm{~s}^{-1}$ \\
\hline$R$ & Earth's radius & $6371 \mathrm{~km}$ \\
\hline$g$ & Acceleration of gravity & $9.81 \mathrm{~ms}^{-2}$ \\
\hline$\rho_{o}$ & Reference density & $1028 \mathrm{~kg} \mathrm{~m}^{-3}$ \\
\hline$S_{o}$ & Reference salinity & 34.7 \\
\hline$C_{p o}$ & Specific heat & $4000 \mathrm{Jkg}^{-1} \mathrm{~K}^{-1}$ \\
\hline$\tau_{T}, \tau_{S}$ & $\begin{array}{l}\text { Restoring time scale for } \\
\text { temperature, salinity }\end{array}$ & 40,70 days \\
\hline$\varepsilon_{c}$ & Closure parameter & 0.6 \\
\hline$\alpha_{o}$ & Sea surface albedo & 0.06 \\
\hline$\varepsilon_{o}$ & $\begin{array}{l}\text { Sea surface emissivity for } \\
\text { longwave radiation }\end{array}$ & 0.96 \\
\hline$C_{S H}^{O A}$ & $\begin{array}{l}\text { Transfer coefficient for } \\
\text { air-sea sensible heat }\end{array}$ & $6 \times 10^{-4}$ \\
\hline$\Delta z_{m}$ & Mixed layer thickness & $70 \mathrm{~m}$ \\
\hline$K_{H}, K_{V}$ & $\begin{array}{l}\text { Horizontal, vertical } \\
\text { mixing coefficients }\end{array}$ & $10^{3}, 5 \times 10^{-5} \mathrm{~m}^{2} \mathrm{~s}^{-1}$ \\
\hline
\end{tabular}

between land masses and the atmosphere, (iii) the effect of water vapor on downward longwave radiation, and (iv) the effect of sea ice on the radiative balance of the atmosphere. The atmospheric parameters are given in Table A2. is

The zonally averaged (around entire latitudinal circles) temperature equation for a one-layer atmosphere

$$
\rho_{a} C_{p a} H_{a} \frac{\partial T_{a}}{\partial t}=Q_{S W}^{A}+Q_{L H}^{A}-Q_{L W}^{t o a}+Q_{L W S H}^{s f c}+Q_{M T}^{A}
$$

Here $T_{a}$ is the zonal average of surface air temperature, $\rho_{a}$ a reference air density, $C_{p a}$ the specific heat of dry air at constant pressure, $H_{a}$ an atmospheric scale height, $Q_{S W}^{A}$ the shortwave radiation absorbed by the atmosphere, $Q_{L H}^{A}$ the release of latent heat during condensation, $Q_{L W}^{t o a}$ the outgoing longwave radiation at the top of the atmosphere, $Q_{L W S H}^{s f c}$ the fluxes of longwave radiation and sensible heat between the atmosphere and the underlying surface (ocean, land and sea ice), and $Q_{M T}^{A}$ a diffusive flux.

The amount of shortwave radiation absorbed by the atmosphere is

$$
Q_{S W}^{A}=(1-a)\left(1-\alpha_{a}\right)\left(1+a \alpha_{s f c}\right) Q_{S W} .
$$

Here $a$ is the atmospheric transmittance for shortwave radiation, $\alpha_{a}$ the atmospheric albedo, $\alpha_{s f c}$ the zonally averaged surface albedo, and $Q_{S W}$ the insolation. The algorithm of Berger (1978) and a solar constant of 1368 $\mathrm{Wm}^{-2}$ are used to compute daily average insolation as a function of latitude, the day number in a year of 365 days, and orbital parameters. $\alpha_{s f c}$ is defined as follows:

$$
\alpha_{s f c}=\sum_{\text {oceans }}\left[(1-A) \alpha_{o}+A \alpha_{i}\right] \frac{\Delta \Lambda_{o}}{2 \pi}+\sum_{\text {land }} \alpha_{l} \frac{\Delta \Lambda_{l}}{2 \pi}
$$

where $\alpha_{o}, \alpha_{i}$ and $\alpha_{l}$ are the ocean, ice, and land albedos, respectively, and $\Delta \Lambda_{l}$ the land angular width. In order to parameterize the effect of continental snow on surface albedo, $\alpha_{l}$ is approximated by

$$
\alpha_{l}= \begin{cases}0.7 & \text { if } T_{a} \leq-10^{\circ} \mathrm{C} \\ 0.025\left(10-T_{a}\right)+0.2 & \text { if }-10^{\circ} \mathrm{C}<T_{a}<10^{\circ} \mathrm{C} \\ 0.2 & \text { if } T_{a} \geq 10^{\circ} \mathrm{C}\end{cases}
$$

Equation (A13) is applied in all the continents except in Antarctica, where a constant land albedo value of 0.85 is used.

The latent heat released to the atmosphere during condensation is

$$
Q_{L H}^{A}=L \rho_{o} \sum_{\text {oceans }} P \frac{\Delta \Lambda_{o}}{2 \pi},
$$


where $L$ is the latent heat of evaporation and $P$ the rate of precipitation over the ocean. Here, we assume a local compensation between changes in $P$ and evaporation, $E$ (Stocker et al, 1992). That is, for a given oceanic grid cell, the magnitude of $P$ and $E$ may change with time but the difference between the two variables remains constant. Thus, $P-E$ values are prescribed and used in conjunction with $E$ values calculated from the model to compute $P$. Note that in Stocker et al (1992), the virtual salt flux $F_{S}^{*}$, diagnosed at the end of an ocean-only equilibrium run under restoring boundary conditions, is assumed to be proportional to $P-E$ (i.e, $P$ and $E$ are the only surface processes that determine sea surface salinity). This procedure, however, is not appropriate in the Arctic Ocean where river runoff has a large influence on surface salinities (and hence on $S^{*}$ ). For this reason, $P$ values are estimated here from

$$
P= \begin{cases}F_{S}^{*} / S_{o}+(1-A) E\left(T_{m}, T_{a}\right) & \text { if } \phi<75^{\circ} \mathrm{N} \\ (P-E)^{*}+(1-A) E\left(T_{m}, T_{a}\right) & \text { if } \phi \geq 75^{\circ} \mathrm{N}\end{cases}
$$

where $(P-E)^{*}$ is a monthly climatological mean of $P-E$ (Kalnay et al, 1996). The evaporation rate $E\left(T_{m}, T_{a}\right)$ is computed from a bulk formula,

$$
E=\frac{\rho_{a}}{\rho_{o}} C_{E}^{O A} W\left[q_{s}\left(T_{m}\right)-r q_{s}\left(T_{a}\right)\right],
$$

where $C_{E}^{O A}$ is the transfer coefficient for moisture, $W$ the monthly climatological value of wind intensity at 10 m elevation (Kalnay et al, 1996), $q_{s}$ the saturation specific humidity, and $r$ the relative humidity. The saturation specific humidity, $q_{s}$, is calculated as a function of temperature according to the Clausius-Clapeyron equation:

$$
q_{s}(T)=\frac{0.622 e_{s}^{*}}{p_{a}} \exp \left[\frac{0.622 L}{R_{d}}\left(\frac{1}{273}-\frac{1}{T}\right)\right]
$$

where $e_{s}^{*}$ is a reference saturation vapor pressure, $p_{a}$ the atmospheric pressure at the surface, and $R_{d}$ the gas constant for dry air.

The outgoing longwave radiation at the top of the atmosphere is

$$
Q_{L W}^{t o a}=\sigma \varepsilon_{a}^{\uparrow} T_{a}^{4},
$$

where $\varepsilon_{a}^{\uparrow}$ is the atmospheric emissivity for upward longwave radiation.

The fluxes of longwave radiation and sensible heat across different types of bottom surfaces are added up to obtain

$$
\begin{aligned}
& Q_{L W S H}^{s f c}=\sum_{\text {oceans }}\left[(1-A) Q_{L W S H}^{O A}+A Q_{L W S H}^{I A}\right] \frac{\Delta \Lambda_{o}}{2 \pi} \\
& +\sum_{\text {land }} Q_{L W S H}^{L A} \frac{\Delta \Lambda_{l}}{2 \pi} .
\end{aligned}
$$

Here, the ocean (sea ice)-air flux of longwave radiation and sensible heat is given by

$$
Q_{L W S H}^{O(I) A}=\sigma\left(\varepsilon_{o(i)} T_{m(i)}^{4}-\varepsilon_{a}^{\downarrow} T_{a}^{4}\right)+D^{O(I) A}\left(T_{m(i)}-T_{a}\right),
$$

where $\varepsilon_{o}\left(\varepsilon_{i}\right)$ is the ocean (sea ice) surface emissivity for longwave radiation, $\varepsilon_{a}^{\downarrow}$ the atmospheric emissivity for downward longwave radiation, $D^{O(I) A}$ a bulk aerodynamic constant for ocean (sea ice)-air sensible heat flux, and $T_{i}$ the sea-ice surface temperature. We assume $D^{O(I) A}=\rho_{a} C_{p a} C_{S H}^{O(I) A} W$, where $C_{S H}^{O(I) A}$ is a transfer coefficient for ocean (sea ice)-air sensible heat flux. The emissivity for downward longwave radiation is computed from

$$
\varepsilon_{a}^{\downarrow}=c f+(1-c f) \varepsilon_{a c l e a r}^{\downarrow},
$$

where $c f$ is the cloud fraction, i.e., the fraction of grid cell area covered by clouds (clouds are assumed to emit longwave radiation as a blackbody), and $\varepsilon_{\text {aclear }}^{\downarrow}$ is the emissivity for downward clear-sky longwave radiation. $\varepsilon_{\text {aclear }}^{\downarrow}$ is computed from the equation of Idso (1981):

$$
\varepsilon_{\text {aclear }}^{\downarrow}=0.55+e_{v} 5.95 \times 10^{-5} \exp \left(\frac{1500}{T_{a}}\right),
$$


Table A2 Atmospheric parameters.

\begin{tabular}{|c|c|c|c|}
\hline$\sigma$ & Stefan-Boltzmann constant & $5.67 \times 10^{-8} \mathrm{~W}\left(\mathrm{~m}^{2} \mathrm{~K}^{4}\right)^{-1}$ & \\
\hline$\rho_{a}$ & Reference density & $1.225 \mathrm{~kg} \mathrm{~m}^{-3}$ & \\
\hline$C_{p a}$ & Specific heat of dry air & $1004 \mathrm{~J} \mathrm{~kg}^{-1} \mathrm{~K}^{-1}$ & \\
\hline$H_{a}$ & Scale height & $8320 \mathrm{~m}$ & \\
\hline$a$ & $\begin{array}{l}\text { Transmittance } \\
\text { for shortwave radiation }\end{array}$ & 0.65 & \\
\hline$L$ & Latent heat of evaporation & $2.5 \times 10^{6} \mathrm{~J} \mathrm{~kg}^{-1}$ & \\
\hline$e_{s}^{*}$ & $\begin{array}{l}\text { Reference saturation vapor } \\
\text { pressure }\end{array}$ & $611 \mathrm{~Pa}$ & \\
\hline$p_{a}$ & Surface pressure & $1013.25 \mathrm{hPa}$ & ${ }^{*}$ The parameter is determined as explained in Appendix C. \\
\hline$R_{d}$ & Gas constant for dry air & $287 \mathrm{~J} \mathrm{~kg}^{-1} \mathrm{~K}^{-1}$ & \\
\hline$r$ & Relative humidity & 0.85 & \\
\hline$\alpha_{a}$ & Albedo* & $0.26-0.44$ & \\
\hline$\varepsilon_{a}^{\uparrow}$ & $\begin{array}{l}\text { Emissivity for upward } \\
\text { longwave radiation* }\end{array}$ & $0.52-0.81$ & \\
\hline$c f$ & Cloud fraction* & $0.12-0.93$ & \\
\hline$C_{E}^{O A}$ & $\begin{array}{l}\text { Transfer coefficient for } \\
\text { moisture* }^{*}\end{array}$ & $1.6 \times 10^{-3}-9.2 \times 10^{-3}$ & \\
\hline$K_{a}$ & Mixing coefficient* & $1.5 \times 10^{5}-3.2 \times 10^{6} \mathrm{~m}^{2} \mathrm{~s}^{-1}$ & \\
\hline
\end{tabular}

where $e_{\nu}$ is the vapor pressure (in millibars) obtained by multiplying the saturation specific humidity, $q_{s}$, by $r p_{a} / 0.622$. Although Idso (1981) used a value of 0.7 for the first term of the right hand side of (A22), a lower value appeared to be required from a test of (A22) against oceanic data (Idso, 1983). Here, a value of 0.55 is used.

Consider now the heat flux from the land to the atmosphere associated with longwave radiation and sensible heat. If the heat storage and humidity on land are neglected, the shortwave radiation absorbed by land, $Q_{S W}^{L}$, is equal to the longwave radiation flux at the land surface plus the land-air sensible heat flux. Thus, $Q_{L W S H}^{L A}$ is approximated by

$$
Q_{L W S H}^{L A}=Q_{S W}^{L}=a Q_{S W}\left(1-\alpha_{a}\right)\left(1-\alpha_{l}\right) .
$$

The diffusive flux in (A10) is

$$
Q_{M T}^{A}=\frac{\rho_{a} C_{p a} H_{a}}{R^{2}} \frac{\partial}{\partial s}\left(K_{a} c^{2} \frac{\partial T_{a}}{\partial s}\right)
$$

where $K_{a}$ is a mixing coefficient. In (A24), the factor within brackets is the heat flux associated with the meridional transport of sensible heat and potential energy. This flux is set to zero at both poles, i.e., a no-flux condition is imposed there.

To solve equation (A10), the Crank-Nicholson scheme is used and the EBM is synchronously coupled to the ocean mixed layer.

\section{A.3 Sea-ice component}

The sea-ice component is largely based on the "zero-layer" thermodynamic sea-ice model of Semtner (1976) with some of the modifications introduced by Parkinson and Washington (1979) for calculating ice concentration. The sea-ice parameters are in Table A3. In each ocean grid cell, the ice is characterized by its thickness $(h)$ and concentration $(A)$ ( $A$ being defined as the fraction of surface grid cell area covered by sea ice). The sea-ice model is synchronously coupled to the ocean mixed layer and the EBM. The sequence of calculations for every sea-ice time step is as follows:

1. Vertical ice growth and melting are calculated first. The decrease in $h$ associated with melting at the ice surface during a time step is

$$
\Delta h=\frac{M^{n-1} \Delta t}{\rho_{i} L_{f}}
$$


where the superscript $n-1$ denotes the beginning of the time step, $M$ is a heat flux (see below), $\Delta t$ the time step used in the sea-ice model, $\rho_{i}$ a reference sea-ice density, and $L_{f}$ the latent heat of fusion. Similarly, a change in $h$ due to melting and accretion at the base of the ice is

$$
\Delta h=\frac{\left(Q^{I}-Q^{O I}\right)^{n-1} \Delta t}{\rho_{i} L_{f}},
$$

where

$$
Q^{I}=\kappa \frac{\left(T_{f r}-T_{i}\right)}{h}
$$

and

$$
Q^{O I}=D^{O I}\left(T_{m}-T_{f r}\right)
$$

Here $\kappa$ is an ice thermal conductivity for heat flux through the ice, $T_{f r}$ the local freezing point of seawater computed from $S_{m}$ (Millero, 1978), and $D^{O I}$ a coefficient for ocean-to-ice sensible heat flux. If vertical melting results in a negative ice volume, then $A$ and $h$ are reset to zero and the energy that was supposed to melt this spurious excess ice is used to heat the ocean mixed layer.

2. The increase in $A$ due to the formation of new ice is

$$
\Delta A=\frac{\rho_{o} C_{p o} \Delta z_{m} \Delta T_{m}}{\rho_{i} L_{f} h^{*}},
$$

where

$$
\Delta T_{m}= \begin{cases}0.1\left(T_{m}^{n-1}-T_{m}^{n}\right) & \text { if } T_{f r}^{n} \leq T_{m}^{n}<0^{\circ} \mathrm{C} \text { and } T_{m}^{n}<T_{m}^{n-1}, \\ T_{f r}^{n}-T_{m}^{n} & \text { if } T_{m}^{n}<T_{f r}^{n}, \\ 0 & \text { otherwise. }\end{cases}
$$

Here $h^{*}$ is the most recently estimated ice thickness for preexisting ice or an initial thickness of $0.3 \mathrm{~m}$ for newly formed ice. The superscript $n$ denotes the end of the sea-ice time step. The heat released by freezing is used to increase $T_{m}^{n}$ by $\Delta T_{m}$. If $A$ exceeds a maximum allowed ice concentration $\left(A_{\max }\right)$, then $A$ is reset to $A_{\max }$ and $h^{*}$ is increased in order to conserve ice volume. The value of $A_{\max }$ in the Southern Hemisphere is smaller than in the Northern Hemisphere because sea ice is less compact in the Southern Ocean than in the Arctic Ocean (Parkinson and Washington, 1979).

In the real ocean, the ocean mixed layer temperature averaged over a large region can be above the freezing point even if the ocean temperature is below the freezing point in a part of this region where sea formation can occur. Thus, if only the second and third equations in (A30) were used in the coarse resolution model, the formation of sea ice would be significantly delayed. To partially remedy this shortcoming, the first equation in (A30) is used. The factor 0.1 improves the agreement between the observed and modeled present-day seasonal cycles of sea-ice area.

3. The parameterization of Parkinson and Washington (1979) for lateral melting is used. If the oceanair heat flux $\left(Q^{O A}\right)$ is negative at the beginning of the time step (i.e., there is a net heat transfer from the atmosphere to the ocean), the decrease in $A$ due to lateral melting during the time step is

$$
\Delta A=\frac{\left[A(1-A) Q^{O A}\right]^{n-1} \Delta t}{\rho_{i} L_{f} h^{*}},
$$

where

$$
Q^{O A}=Q_{L W S H}^{O A}+Q_{L H}^{O}-Q_{S W}^{O} .
$$

Here $Q_{L H}^{O}=L \rho_{o} E$ is the latent heat flux at the sea surface and $Q_{S W}^{O}$ the shortwave radiation flux at sea surface, obtained from an expression similar to (A23). In (A31), it is assumed that a fraction $A(1-A)$ of the air-to-sea heat flux $Q^{O A}$ melts sea ice laterally instead of heating the ocean mixed layer during the time step. Consequently, a corrective change in $T_{m}^{n}$ is calculated,

$$
\Delta T_{m}=\frac{\left[A(1-A) Q^{O A}\right]^{n-1} \Delta t}{\rho_{o} C_{p o} \Delta z_{m}} .
$$

Again, if a negative ice volume is obtained as a consequence of excessive lateral melting, $A$ and $h$ are reset to zero and $T_{m}$ is increased as explained above. 
Table A3 Sea-ice parameters.

\begin{tabular}{lll}
\hline$A_{\max }$ & $\begin{array}{l}\text { Maximum sea-ice concentration } \\
\text { in the Southern, Northern Hemisphere }\end{array}$ & $0.9,0.99$ \\
& \\
$L_{f}$ & Latent heat of fusion & $3.3 \times 10^{5} \mathrm{~J} \mathrm{~kg}^{-1}$ \\
$\rho_{i}$ & Reference density & $0.9 \times \rho_{o}$ \\
$D^{O I}$ & $\begin{array}{l}\text { Coefficient for ocean-sea ice } \\
\text { sensible heat flux }\end{array}$ & $20 \mathrm{~W} \mathrm{~m}^{-2} \mathrm{~K}^{-1}$ \\
$\kappa$ & Thermal conductivity & $2 \mathrm{Wm}^{-1} \mathrm{~K}^{-1}$ \\
$\alpha_{i}$ & Albedo & 0.65 \\
$C_{S H}^{I A}$ & $\begin{array}{l}\text { Coefficient for air-sea ice } \\
\text { sensible heat flux }\end{array}$ & $10^{-3}$ \\
$\varepsilon_{i}$ & $\begin{array}{l}\text { Sea-ice surface emissivity for } \\
\text { longwave radiation }\end{array}$ & 0.97 \\
$T_{m e l t}$ & Melting point & $0{ }^{\circ} \mathrm{C}$ \\
\hline
\end{tabular}

4. With all the finite changes in $h$ and $A$ calculated as above, the surface ice temperature is updated. At the end of the sea-ice time step, the following energy balance holds at the ice surface:

$$
Q_{L W S H}^{I A}-Q^{I}-Q_{S W}^{I}=0,
$$

where $Q_{S W}^{I}$ is the shortwave radiation flux at the ice surface given by an expression analogous to (A23). The Newton-Raphson method is used to solve (A34) for $T_{i}$. If the diagnosed $T_{i}$ is above the melting point of ice, $T_{m e l t}, T_{i}$ is reset to $T_{m e l t}$ and the left hand side of (A34) is recomputed to estimate a residual $M$, needed for the surface melting computation described by (A25). After the diagnosis of $T_{i}$ is completed, $Q_{L W S H}^{I A}$ and $Q^{I}$ are updated. At this point, the ocean-to-ice sensible heat flux $Q^{O I}$ is also updated.

5. Finally, the total change in ice volume per unit area arising from the thermodynamic calculations (1-4), $\Delta(h A)$, is used to estimate the change in ocean mixed layer salinity,

$$
\Delta S_{m}=\frac{\rho_{i} S_{o} \Delta(h A)}{\rho_{o} \Delta z_{m}} .
$$

\section{Appendix B: Model spinup and output saving procedures}

A two-stage procedure is used to spin up the model under present-day climate forcing. First, the ocean circulation component is spun up for $5 \mathrm{kyr}$ under restoring boundary conditions from a state of rest and homogeneous $(T, S)$. When a global model domain is used, a salinity anomaly of $0.3(0.2)$ is added to the restoring $S^{*}$ values between $55^{\circ} \mathrm{N}-80^{\circ} \mathrm{N}\left(70^{\circ} \mathrm{S}-60^{\circ} \mathrm{S}\right)$, which results in a better agreement between the modeled and climatological latitude-depth distributions of $(T, S)$. Similarly, $S^{*}$ is increased by 0.3 between $55^{\circ} \mathrm{N}-75^{\circ} \mathrm{N}$ and $70^{\circ} \mathrm{S}-65^{\circ} \mathrm{S}$ when the model version without an Arctic Ocean basin is used. Second, the sea-ice and atmospheric components are coupled to the spun-up ocean model and the coupled model is integrated for another $7 \mathrm{kyr}$ to reach a new equilibrium state. The initial conditions for this coupled run are (i) fields of $(T, S)$ and streamfunction from the ocean spinup, (ii) climatological values of December surface air temperature (Kalnay et al, 1996), and (iii) an ice-free ocean (i.e., $h=A=0$ everywhere at the moment of coupling). The atmosphere model is forced with daily insolation values computed with present-day orbital parameters from Berger (1978).

In the time-dependent solutions, values of area and volume of sea ice are saved every $200 \mathrm{yr}$. Latitudinal profiles of annual mean surface air temperature and latitude-depth sections of annual mean ocean temperature are saved every $2 \mathrm{kyr}$. As in BHW99, we found that the model looses memory of the initial conditions after a few thousand years. For this reason, the first $10 \mathrm{kyr}$ of the time-dependent solutions are not used for statistical analysis because these initial parts of the solutions are affected by the initial conditions. Note that only a small fraction of the complete time series ( $2 \mathrm{Myr}$ in length) is discarded with this approach.

\section{Appendix C: Atmospheric parameters}

This appendix describes the determination of five atmospheric parameters: $K_{a}(\phi), \alpha_{a}(\phi), c f(\phi, j), \varepsilon_{a}^{\uparrow}(\phi)$, and $C_{E}^{O A}(\phi, j)$. Some of these parameters depend not only on latitude $(\phi)$ but also on the ocean basin (indexed 
by $j$ ). In order to compute these parameters, we adopt the method of Stocker et al (1992) as modified for a seasonal model by Schmittner and Stocker (2001). Thus, outputs from the ocean spinup under restoring boundary conditions are used in conjunction with climatological data to derive the five parameters. In this manner, any climate drift that would result from coupling the ocean model with other components is minimized. As in Schmittner and Stocker (2001), only annual means of climatological and model variables are used. Thus, the seasonal cycle is not considered for the five atmospheric parameters. Here, we use climatologies of $E(\phi, j), W(\phi, j), T_{a}(\phi), Q_{L W}^{t o a}(\phi)$, and zonally averaged upward shortwave radiation flux at the top of the atmosphere, denoted by $Q_{S W}^{\uparrow}(\phi)$ (Kalnay et al, 1996). Also, we use annual and zonal climatological means of $A$ from Walsh (1978) and Zwally et al (1983). Annual insolation values, which are also needed for determining EBM parameters, are computed from the present-day orbital parameters of Berger (1978). We diagnose annual means of $T_{m}(\phi, j), Q^{O A}(\phi, j)$, and $F_{S}^{*}(\phi, j)$ from the last 100 years of the ocean spinup, i.e., the last two fluxes are computed as

$$
\begin{gathered}
Q^{O A}=\frac{\rho_{o} C_{p o} \Delta z_{m}}{\tau_{h}}\left(T_{m}-T^{*}\right), \\
F_{S}^{*}=\frac{\Delta z_{m}}{\tau_{s}}\left(S_{m}-S^{*}\right) .
\end{gathered}
$$

The specific methods for determining the EBM parameters are now described. They are applied to the entire model domain unless stipulated otherwise.

We first consider the derivation of $K_{a}$. Assuming an ice-free ocean and thermodynamic equilibrium, we combine equations (A10), the first equation in (A15) and (A32) to obtain:

$$
\begin{gathered}
K_{a}=\frac{R^{2}}{H_{a} \rho_{a} C_{p a} c^{2} \frac{\partial T_{a}}{\partial s} \int_{-1}^{s}\left[Q_{L W}^{t o a}+Q_{S W}^{\uparrow}-Q_{S W}\right.} \\
\left.-\sum_{\text {oceans }}\left(Q^{O A}+\frac{L \rho_{o} F_{S}^{*}}{S_{o}}\right) \frac{\Delta \Lambda_{o}}{2 \pi}\right] d s^{\prime}
\end{gathered}
$$

Then, the right hand side of (C3) is determined by using (i) the climatologies for $T_{a}, Q_{L W}^{t o a}$, and $Q_{S W}^{\uparrow}$, (ii) the annual mean insolation, and (iii) the heat and salt fluxes diagnosed from the ocean model spinup. No negative $K_{a}$ values were obtained in this manner.

Second, the atmospheric albedo, $\alpha_{a}$, is calculated from

$$
\alpha_{a}=1-\frac{Q_{S W}-Q_{S W}^{\uparrow}}{Q_{S W}\left(1-a^{2} \alpha_{s f c}\right)},
$$

where $Q_{S W}$ and $Q_{S W}^{\uparrow}$ are replaced by their annual means. In (C4), $\alpha_{s f c}$ is computed using the climatological $A$ values and the land albedo values $\alpha_{l}=0.85(0.2)$ south (north) of $70^{\circ} \mathrm{S}$.

Next, the two-step determination of $c f$ is described. First, an ice-free ocean is assumed and equation (A32) is solved for $\varepsilon_{a}^{\downarrow}$ in order to express this emissivity as a function of insolation, atmospheric albedo, climatological estimates $\left(T_{a}, E, W\right)$, and model variables from the ocean spinup $\left(T_{m}, Q^{O A}\right)$. By doing this, values of $\varepsilon_{a}^{\downarrow}$ are obtained south of $75^{\circ} \mathrm{N}$. North of $75^{\circ} \mathrm{N}, \varepsilon_{a}^{\downarrow}$ is fixed to 0.93 . Second, equations (A21) and (A22) are combined, so the climatological values of $T_{a}$ and the $\varepsilon_{a}^{\downarrow}$ values obtained in the previous step can be used to determine $c f$. All the $c f$ estimates derived in this manner are within the interval $(0,1)$.

Finally, we describe the calculation of $\varepsilon_{a}^{\uparrow}$ and $C_{E}^{O A}$. To determine $\varepsilon_{a}^{\uparrow}$ we solve (A18) by inserting the climatological values of $T_{a}$ and $Q_{L W}^{t o a}$ in this equation. Similarly, $C_{E}^{O A}$ is determined from equation (A16), the model values of $T_{m}$, and the climatologies for $E, W$ and $T_{a}$.

\section{References}

Berger A, Loutre MF (1991) Insolation values for the climate of the last 10 million years. Quaternary Sci Rev 10:297-317 
Berger AL (1978) Long-term variations of daily insolation and Quaternary climate changes. J Atmos Sci 35:2362-2367

Brickman D, Hyde W, Wright DG (1999) Filtering of Milankovitch cycles by the thermohaline circulation. J Climate 12:1644-1658

Broecker WS, Peacock SL, Walker S, Weiss R, Fahrbach E, Schroeder M, Milkolajewicz U, Heinze C, Key R, Peng TH, Rubin S (1998) How much deep water is formed in the Southern Ocean? J Geophys Res 103:15,833-15,843

Cronin TM, Dowsett HJ, Dwyer GS, Baker PA, Chandler MA (2005) Mid-Pliocene deepsea bottom-water temperatures based on ostracode $\mathrm{Mg} / \mathrm{Ca}$ ratios. Mar Micropaleontol 54:249-261

Doney SC, Lindsay K, Caldeira K, Campin JM, Drange H, Dutay JC, Follows M, Gao Y, Gnanadesikan A, Gruber N, Ishida A, Joos F, Madec G, Maier-Reimer E, Marshall JC, Matear RJ, Monfray P, Mouchet A, Najjar R, Orr JC, Plattner GK, Sarmiento J, Schlitzer R, Slater R, Totterdel IJ, Weiring MF, Yamanaka Y, Yool A (2004) Evaluating global ocean carbon models: The importance of realistic physics. Global Biogeochem Cycles 18, DOI 10.1029/2003GB002150

Döös K, Webb DJ (1994) The Deacon cell and other meridional cells of the Southern Ocean. J Phys Oceanogr 24:429-442

Dwyer GS, Cronin TM, Baker PA, Raymo ME, Buzas JS, Corrège T (1995) North Atlantic deepwater temperature change during late Pliocene and late Quaternary climatic cycles. Science 270:1347-1351

Huybers P (2006) Early Pleistocene glacial cycles and the integrated summer insolation forcing. Science 313:508-511, DOI 10.1126/science.1125249

Huybers P, Tziperman E (2008) Integrated summer insolation forcing and 40,000-year glacial cycles: The perspective from an ice-sheet/energy-balance model. Paleoceanography 23, DOI 10.1029/2007PA001463

Idso SB (1981) A set of equations for full spectrum and 8-14 $\mu \mathrm{m}$ and 10.5-12.5 $\mu \mathrm{m}$ thermal radiation from cloudless skies. Water Resour Res 17:295-304

Idso SB (1983) On calculating thermal radiation from cloudless skies. Arch Met Geoph Biocl 32:53-57

Jouzel J, Masson-Delmotte V, Cattani O, Dreyfus G, Falourd S, Hoffmann G, Minster B, Nouet J, Barnola JM, Chappellaz J, Fischer H, Gallet JC, Johnsen S, Leuenberger M, Loulergue L, Luethi D, Oerter H, Parrenin F, Raisbeck G, Raynaud D, Schilt A, Schwander J, Selmo E, Souchez R, Spahni R, Stauffer B, Steffensen JP, Stenni B, Stocker TF, Tison JL, Werner M, Wolff EW (2007) Orbital and millennial Antarctic climate variability over the past 800,000 years. Science 317:793-796, DOI 10.1126/science.1141038

Kalnay E, Kanamitzu M, Kistler R, Collins W, Deaven D, Gandin L, Iredell M, Saha S, White G, Woollen J, Zhu Y, Chelliah M, Ebisuzaki W, Higgins W, Janowiak J, Mo KC, Ropelewski C, Wang J, Leetmaa A, Reynolds R, Jenne R, Joseph D (1996) The NCEP/NCAR 40-year reanalysis project. Bull Amer Meteor Soc 77:437-471

Lisiecki LE, Raymo ME (2005) A Pliocene-Pleistocene stack of 57 globally distributed benthic $\delta^{18}$ O records. Paleoceanography 20, DOI 10.1029/2004PA001071

Lisiecki LE, Raymo ME (2007) Plio-Pleistocene climate evolution: trends and transitions in glacial cycle dynamics. Quaternary Sci Rev 26, DOI 10.1016/j.quascirev.2006.09.005

Millero FJ (1978) Freezing point of seawater. UNESCO Tech. Pap. Mar. Sci. 28, $8^{\text {th }}$ report of the Joint Panel on Oceanographic Tables and Standards, Annex 6.

NODC (1998) Levitus World Ocean Atlas 1998. Natl. Oceanogr. Data Cent., Natl. Oceanic and Atmos. Admin., [Available online at http://www.cdc.noaa.gov/cdc/] 
Parkinson CL, Washington WM (1979) A large-scale numerical model of sea ice. J Geophys Res 84:311-337

Petit JR, Jouzel J, Raynaud D, Barkov NI, Barnola JM, Basile I, Bender M, Chappellaz J, Davis M, Delaygue G, Delmotte M, Kotlyakov VM, Legrand M, Lipenkov VY, Lorius C, Pépin L, Ritz C, Saltzman E, Stievenard M (1999) Climate and atmospheric history of the past 420,000 years from the Vostok ice core, Antarctica. Nature 399:429-436

Roemmich D, Wunsch C (1985) Two transatlantic sections: meridional circulation and heat flux in the subtropical North Atlantic ocean. Deep-Sea Res 32:619-664

Schmittner A, Stocker TF (2001) A seasonally forced ocean-atmosphere model for paleoclimate studies. J Climate 14:1055-1068

Semtner AJ (1976) A model for the thermodynamic growth of sea ice in numerical investigation of climate. J Phys Oceanogr 6:379-389

Shackleton NJ, Hall MA, Pate D (1995) Pliocene stable isotope stratigraphy of site 846. In: Proceedings of the Ocean Drilling Program, Scientic Results, vol 138, pp 337-355

Smolarkiewicz PK (1983) A simple positive definite advection scheme with small implicit diffusion. Mon Wea Rev 111:479-486

Stocker TF, Wright DG, Mysak LA (1992) A zonally averaged, coupled ocean-atmosphere model for paleoclimate studies. J Climate 5:773-797

Tiedemann R, Sarnthein M, Shackleton NJ (1994) Astronomic timescale for the Pliocene Atlantic $\delta^{18} \mathrm{O}$ and dust flux records of Ocean Drilling Program site 659. Paleoceanography 9:619-638

Walsh J (1978) A data set on Northern Hemisphere sea ice extent, 1953-76. Tech. Rep. GD-2, Glaciological Data, World Data Center for Glaciology (Snow and Ice)

Wright DG (1997) An equation of state for use in ocean models: Eckart's formula revisited. J Atmos Oceanic Technol 14:735-740

Wright DG, Stocker TF (1991) A zonally averaged ocean model for the thermohaline circulation. Part I: model development and flow dynamics. J Phys Oceanogr 21:1713-1724

Wright DG, Stocker TF (1992) Sensitivities of a zonally averaged global ocean circulation model. J Geophys Res 97:12,707-12,730

Wright DG, Stocker TF (1993) Younger Dryas experiments. In: Peltier WR (ed) Ice in the Climate System, Springer-Verlag, pp 395-416

Wright DG, Vreugdenhil CB, Hughes TMC (1995) Vorticity dynamics and zonally averaged ocean circulation models. J Phys Oceanogr 25:2141-2154

Wright DG, Stocker TF, Mercer D (1998) Closures used in zonally averaged ocean models. J Phys Oceanogr 28:791-804

Zwally HJ, Comiso J, Parkinson C, Campbell W, Carsey F, Gloerson P (1983) Antarctic sea ice, 1973-1976: Satellite passive microwave observations. NASA, 206 pp 